OPEN ACCESS

Edited by:

Martina Cappelletti,

University of Bologna, Italy

Reviewed by:

Haiyuan Cai,

University of Maryland

Baltimore County,

United States

Yuli Wei,

Shanghai Ocean University,

China

Intikhab Alam,

King Abdullah University of Science and Technology, Saudi Arabia

Fatemeh Salimi,

Damghan University,

Iran

*Correspondence:

Yu-Qin Zhang

zhyuqin@126.com

Specialty section: This article was submitted to Extreme Microbiology,

a section of the journal

Frontiers in Microbiology

Received: 02 August 2021 Accepted: 05 October 2021 Published: 05 November 2021

Citation:

Jiang Z-M, Zhang B-H, Sun H-M,

Zhang T, YU L-Y and Zhang Y-Q

(2021) Properties of Modestobacter

deserti sp. nov., a Kind of Novel

Phosphate-Solubilizing Actinobacteria

Inhabited in the Desert Biological

Soil Crusts.

Front. Microbiol. 12:742798.

doi: 10.3389/fmicb.2021.742798

\section{Properties of Modestobacter deserti sp. nov., a Kind of Novel Phosphate- Solubilizing Actinobacteria Inhabited in the Desert Biological Soil Crusts}

\author{
Zhu-Ming Jiang ${ }^{1}$, Bing-Huo Zhang ${ }^{2}$, Hong-Min Sun ${ }^{1}$, Tao Zhang ${ }^{1}$, Li-Yan Yu $^{1}$ and \\ Yu-Qin Zhang ${ }^{1 *}$
}

'Institute of Medicinal Biotechnology, Chinese Academy of Medical Sciences \& Peking Union Medical College, Beijing, China, ${ }^{2}$ College of Life Science, Jiujiang University, Jiujiang, China

Three Gram-stain-positive, aerobic, motile actinobacterial strains designated as CPCC 205119', CPCC 205215, and CPCC 205251 were isolated from different biological soil crust samples collected from Tengger Desert, China. The 16S rRNA gene sequence comparison of these three strains showed they had almost identical 16S rRNA genes, which were closely related to members of the family Geodermatophilaceae, with the highest similarities of $96.3-97.3 \%$ to the species of Modestobacter. In the phylogenetic tree based on 16S rRNA gene sequences, these isolates clustered into a subclade next to the branch containing the species of Modestobacter lapidis and Modestobacter multiseptatus, within the lineage of the genus Modestobacter. The comparative genomic characteristics (values of $\mathrm{ANI}, \mathrm{dDDH}, \mathrm{AAl}$, and POCP) and the phenotypic properties (morphological, physiological, and chemotaxonomic characteristics) of these isolates readily supported to affiliate them to the genus Modestobacter as a single separate species. For which, we proposed that the isolates CPCC 205119 ${ }^{\top}$, CPCC 205215, and CPCC 205251 represent a novel species of the genus Modestobacter as Modestobacter deserti sp. nov. CPCC $205119^{\top}\left(=112 \mathrm{~A}-02624=\mathrm{NBRC} 113528^{\top}=\mathrm{KCTC} 49201^{\top}\right)$ is the type strain. The genome of strain CPCC $205119^{\top}$ consisted of one chromosome $(4,843,235$ bp) containing 4,424 coding genes, 48 tRNA genes, five rRNA genes, three other ncRNA genes, and 101 pseudogenes, with $G+C$ content of $74.7 \%$. The wholegenome sequences analysis indicated that this species contained alkaline phosphatase genes (phoA/phoD), phosphate transport-related genes (phoU, phnC, phnD, phnE, phoB, phoH, phoP, phoR, pitH, ppk, pstA, pstB, pstC, and pstS), trehalose-phosphate synthase gene (ots $A$ ), trehalose 6-phosphate phosphatase gene (otsB) and other encoding genes for the properties that help the microorganisms to adapt to harsh environmental conditions prevalent in deserts. Strains of this species could solubilize tricalcium phosphate $\left[\mathrm{Ca}_{3}\left(\mathrm{PO}_{4}\right)_{2}\right]$ and phytin, assimilate pyrophosphate, thiophosphate, dithiophosphate, phosphoenol pyruvate, 2-deoxy-d-glucose-6-phosphate, and cysteamine-S-phosphate.

Keywords: Modestobacter deserti, average nucleotide identity, pan-genome, phenotype, genotype, biological soil crusts 


\section{INTRODUCTION}

Water scarcity, violent temperature fluctuation, strong ultraviolet radiation, and low-substrate supply are the key abiotic stress factors for life in desert environments. Microbiological soil crusts, the primary stage of biological soil crusts, contribute greatly in stabilization of the sandy surface, soil formation, and carbon and nitrogen assimilation, which provide foundation for other organisms to survive. The "National Desert Ecological Reserve" (NDER) located in Shapotou desert region, on the south east edge of the Tengger Desert, south to the Yellow River, in the northwest of China is the first Chinese NDER. This NDER acts as a model for studying the development of biological soil crusts. Previous study (Sun et al., 2015) found that the members of the family Geodermatophilaceae (Normand, 2006) were ubiquitous in different types of crusts in Shapotou NDER. Among the validly described species of the family Geodermatophilaceae, most validly described type strains, especially the Modestobacter (a major genus in the family Geodermatophilaceae) members were isolated from harsh environments, including desert soils (Busarakam et al., 2016; Golińska et al., 2020), sandstone (Trujillo et al., 2015), stone surfaces (Normand et al., 2012; Montero-Calasanz et al., 2019), as well as the newly recognized species Modestobacter excelsi ${ }^{1}$ from a high altitude Atacama Desert soil (Golinska et al., 2020). The genome study of Modestobacter revealed that the multiple copies of genes, such as coxSML (carbon monoxide dehydrogenase related genes), katA (catalase coding gene), and uvrACD (UvrABC system protein coding genes; Chouaia et al., 2012; Gtari et al., 2012; Sghaier et al., 2016) may serve as the genetic basis to help the strains to adapt to extreme ecological niches. Therefore, Modestobacter strains from the desert biological soil crusts may be ideal model microorganisms to investigate the microbiological soil crusts development in depth. At the time of writing, the genus Modestobacter comprised of 11 validly named species. ${ }^{1}$ Generally, the members of the genus Modestobacter are characterized as Gram-staining-positive, aerobic, pink-pigmented, and short rod-shaped actinobacteria, with major polar lipid composition of diphosphatidylglycerol (DPG), phosphatidylglycerol (PG), phosphatidylethanolamine

$(\mathrm{PE})$, phosphatidylmethylethanolamine (PME), phosphatidylinositol (PI), and phosphatidylinositol mannosides (PIM). The major respiratory quinone is $\mathrm{MK}-9\left(\mathrm{H}_{4}\right)$, and $\mathrm{MK}-8\left(\mathrm{H}_{4}\right), \mathrm{MK}-9\left(\mathrm{H}_{6}\right)$, MK- $9\left(\mathrm{H}_{2}\right)$, and $\mathrm{MK}-10\left(\mathrm{H}_{4}\right)$ may be present. Major fatty acids are iso- $\mathrm{C}_{16: 0}$ and iso- $\mathrm{C}_{15: 0}$. The $\mathrm{DNA} \mathrm{G}+\mathrm{C}$ content ranges from 68 to $74.1 \%$.

The primary goal of the present research was to collect and identify the Modestobacter cultures from Shapotou NDER, and study the properties of Modestobacter members inhabiting in the biological soil crusts in desert niches. The detailed

${ }^{1}$ https://lpsn.dsmz.de/genus/modestobacter

Abbreviations: ANI, Average nucleotide identity; dDDH, Digital DNA-DNA hybridization; AAI, Amino acid identity; POCP, Percentage of conserved proteins; BSCs, Biological soil crusts. phenotypic and genotypic properties resulted from these strains could be helpful to systematically demonstrate their ecological adaptation mechanism and their ecological function. As a result, strains CPCC 205119 , CPCC 205215, and CPCC 205251 were isolated from biological soil crusts collected from Tengger Desert, showing phosphate-solubilizing activity. Based on the phenotypic and genotypic data, a novel species Modestobacter deserti sp. nov. is proposed, with the isolate CPCC $205119^{\mathrm{T}}$ as the type strain.

\section{MATERIALS AND METHODS}

\section{Acquisition of Samples}

The moss-dominated soil crusts samples designated IMB12100 and IMB12108 were collected from Cuiliu ditch $\left(37^{\circ} 25^{\prime} 38^{\prime \prime} \mathrm{N}\right.$, $\left.104^{\circ} 35^{\prime} 9^{\prime \prime} \mathrm{E}, 1,691 \mathrm{mH}\right)$ and Yiwan spring $\left(37^{\circ} 35^{\prime} 50^{\prime \prime} \mathrm{N}\right.$, $\left.104^{\circ} 34^{\prime} 59^{\prime \prime} \mathrm{E}, 1,329 \mathrm{mH}\right)$, respectively, and the cyanobacteriadominated soil crusts sample CCL12125 was from the Northroad experimental area $\left(37^{\circ} 25^{\prime} 38^{\prime \prime} \mathrm{N}, 104^{\circ} 35^{\prime} 8^{\prime \prime} \mathrm{E}, 1,340 \mathrm{mH}\right)$, in the middle of Shapotou NDER $\left(36^{\circ} 39^{\prime}-37^{\circ} 41^{\prime} \mathrm{N}, 104^{\circ} 25^{\prime}-\right.$ $\left.105^{\circ} 40^{\prime} \mathrm{E}, 1,300-1,700 \mathrm{mH}\right)$. Different samples were sealed in sterilized envelopes following collection and taken to the laboratory within 1 week of collection. All samples were immediately processed for the isolation of microorganisms after arriving at the laboratory, and the remaining samples were maintained at $-80^{\circ} \mathrm{C}$.

\section{Isolation and Identification of Modestobacter Strains}

Dilution plating method was employed for the isolation of microorganisms from the sand samples. Approximately $0.2-0.3 \mathrm{ml}$ of the $10^{-3}$ dilution was dropped into isolation agar Petri dishes and spread evenly on the surface. The isolation medium of PYG $\left(\mathrm{g} \mathrm{L}^{-1}\right.$; peptone 3 , yeast extract 5 , glycerol 10 , glycine betaine 1.25 , sodium pyruvate 1.25 , and $\mathrm{pH} 7.5)$ and agar $(1.5 \% \mathrm{w} / \mathrm{v})$ was prepared and autoclaved separately, to avoid high $\mathrm{H}_{2} \mathrm{O}_{2}$ concentration in media prepared by autoclaving agar and phosphate buffer together (Tanaka et al., 2014), and then mixed the agar with the nutrient content when cooling to $55^{\circ} \mathrm{C}$. Subsequently, supplemented with $0.1 \%(v / v)$ of compound trace salts solution $\left(\mathrm{FeSO}_{4} \cdot 7 \mathrm{H}_{2} \mathrm{O}\right.$ $0.2 \mathrm{~g}, \mathrm{MnCl}_{2} \cdot 2 \mathrm{H}_{2} \mathrm{O} 0.1 \mathrm{~g}, \mathrm{ZnSO}_{4} \cdot 7 \mathrm{H}_{2} \mathrm{O} 0.1 \mathrm{~g}$, sterilized water $100 \mathrm{ml}), 1 \%(v / v)$ of compound vitamin mixture (vitamin B1 $1 \mathrm{mg}$, vitamin B2 $1 \mathrm{mg}$, vitamin B3 $1 \mathrm{mg}$, vitamin B6 $1 \mathrm{mg}$, phenylalanine $1 \mathrm{mg}$, biotin $1 \mathrm{mg}$, alanine $0.3 \mathrm{mg}$, suspended in $100 \mathrm{ml}$ sterilized water) and cycloheximide to the final concentration of $50 \mathrm{mg} \mathrm{L}^{-1}$. Vitamin mixture and cycloheximide were all filter-sterilized.

The Petri dishes spread with soil suspension were incubated at $28^{\circ} \mathrm{C}$ for 3 weeks and distinct colonies were streaked into newly prepared PYG agar dishes to purify the cultures. The purified isolates were maintained on PYG slants at $4^{\circ} \mathrm{C}$ and also as glycerol suspensions $(20 \%, v / v)$ at $-80^{\circ} \mathrm{C}$.

The Modestobacter-like strains were primarily identified according to the $16 \mathrm{~S}$ rRNA gene sequence comparison following next steps. 
Extraction of genomic DNA and PCR amplification of the strain's 16S rRNA gene were carried out as described by Li et al. (2007). The obtained sequence was compared with available $16 \mathrm{~S}$ rRNA gene sequences from GenBank using the BLAST program and the EzTaxon-e server ${ }^{2}$ to determine an approximate taxonomic affiliation (Yoon et al., 2017a). Multiple sequence alignment and analysis of the data were performed by using the molecular evolutionary genetics analysis (MEGA) software package version X (Kumar et al., 2018). The phylogenetic trees were reconstructed by the software package MEGA version X using the neighbour-joining (Kimura, 1979) and confirmed by maximum-likelihood (Felsenstein, 1981) and maximumparsimony (Kluge and Farris, 1969) tree-making methods. Bootstrap analysis with 1,000 replicates was performed to obtain the confidence level of the branches (Felsenstein, 1985).

\section{Growth Conditions and Morphological Tests}

Growth characteristics of the strains were tested using ISP 2 (Shirlng and Gottlieb, 1966), GYM (g L ${ }^{-1}$; glucose 4, yeast extract 4, malt extract 10, calcium carbonate 2, $\mathrm{pH} 7.5$ ), Tryptic soy agar (TSA, Difco), Reasoner's 2A agar (R2A, Difco), nutrition agar (NA), and PYG agar. The temperature range for growth was tested at $4,10,15,20,28,30,32,35,37$, and $40^{\circ} \mathrm{C}$ using ISP 2 broth for cultivation 2 weeks. The $\mathrm{pH}$ range (5.0-12.0, at intervals of $1 \mathrm{pH}$ unit) for growth was observed in ISP 2 broth using the buffer system described by Xu et al. (2005). Tolerance to $\mathrm{NaCl}$ was examined using GYM broth as the basal medium with different $\mathrm{NaCl}$ concentrations $[0-10 \%(w / v$; at $1 \%$ intervals)].

Colonies characteristics and pigments production were observed and recorded after 3-day incubation on GYM agar $^{3}$ at $28^{\circ} \mathrm{C}$. The Gram reaction was tested by the standard Gramstaining method as described by Magee et al. and observed using light microscopy (BH-2, Olympus). Motility of cells was examined on GYM semi-solid medium agar $(0.3 \%, w / v)$ and then checked using light microscopy. The cellular morphology of the test strains was studied using transmission electron microscopy (JEOL JEM-1010) after 6-day incubation on GYM semi-solid slant agar. Before cells were mounted on formvarcoated copper grids (Electron Microscopy Science), they were negatively stained using $2 \%(w / v)$ uranyl acetate for $15 \mathrm{~s}$.

\section{Physiological Tests}

The reference strains of $M$. lapidis DSM $100206^{\mathrm{T}}$ and $M$. multiseptatus DSM $44406^{\mathrm{T}}$ obtained from DSMZ were carried out some assays in parallel.

The assimilation of carbon compounds, nitrogen sources, phosphorus, and sulfur sources were tested at $28^{\circ} \mathrm{C}$ using Biolog GEN III, PM3B, and PM4A Microplates, respectively, in an Omnilog device (BIOLOG Inc., Hayward, CA, United States). Other metabolic characters were determined by API $50 \mathrm{CH}$ and API ZYM test kits (bioMerieux) according to the

${ }^{2}$ http://eztaxon-e.ezbiocloud.net

${ }^{3} \mathrm{https} / /$ www.dsmz.de/collection/catalogue/details/culture/DSM-100206 manufacturer's instructions. Results were evaluated after incubation at $28^{\circ} \mathrm{C}$ for $72-168 \mathrm{~h}$. The oxidase activity was detected using API oxidase reagent (bioMeriéux) according to the manufacturer's instructions. The catalase activity was determined by observation of bubble production in 3\% $(v / v)$ $\mathrm{H}_{2} \mathrm{O}_{2}$. The abilities of strains to produce $\mathrm{H}_{2} \mathrm{~S}$ and indole, hydrolysis of cellulose, gelatin, and starch were examined according to previously described procedures (Zhou et al., 1998; Yuan et al., 2008).

The ability of these three strains and the reference strains M. lapidis DSM $100206^{\mathrm{T}}$ and M. multiseptatus DSM $44406^{\mathrm{T}}$ to solubilize insoluble phosphate were determined on plates using phosphate-solubilizing media and confirmed using broth culture method (Zhang et al., 2016), with little modification addressed as follows.

Inocula for phosphate solubilization test were prepared from culture grown in GYM broth $\left(28^{\circ} \mathrm{C}, 3\right.$ days $)$. Cultures were centrifuged $\left(4,860 \mathrm{~g}, 20 \mathrm{~min}, 4^{\circ} \mathrm{C}\right)$, and the collected biomass re-suspended in small aliquots of sterilized distilled water. Cell suspension, adjusted to approximately $1 \times 10^{6} \mathrm{CFU} / \mathrm{ml}$, was inoculated into the phosphate-solubilizing medium $\left(\mathrm{gL}^{-1}\right)$ [glucose, 10; $\left(\mathrm{NH}_{4}\right)_{2} \mathrm{SO}_{4}, 0.5 ; \mathrm{MgSO}_{4} \cdot 7 \mathrm{H}_{2} \mathrm{O}, 0.3 ; \mathrm{NaCl}, 0.3 ; \mathrm{KCl}, 0.3$; $\mathrm{FeSO}_{4} \cdot 4 \mathrm{H}_{2} \mathrm{O}, 0.036 ; \mathrm{MnSO}_{4} \cdot 4 \mathrm{H}_{2} \mathrm{O}, 0.03$; insoluble phosphorus sources, 2 (including tricalcium phosphate or phytin); distilled water, $1,000 \mathrm{ml} ; \mathrm{pH} \mathrm{7.0]}$. For the control, the bacterial cell inoculum was replaced with sterile water. Culture broth was centrifuged $\left(4,860 \mathrm{~g}, 20 \mathrm{~min}, 4^{\circ} \mathrm{C}\right)$ on the 2 nd day of incubation, and the amount of available phosphorus in the supernatant determined colorimetrically using standard protocol as described previously (Ministry of Agriculture of the People's Republic of China, 2010).

Reaction mixture containing $5 \mathrm{ml}$ supernatant, $5 \mathrm{ml} \mathrm{Mo-Sb}$ reagent solution were adjusted to a final volume of $50 \mathrm{ml}$ with distilled water, briefly mixed and kept incubated at $20^{\circ} \mathrm{C}$ for $30 \mathrm{~min}$. Absorbance of the reaction mixture was monitored at $700 \mathrm{~nm}$ against a standard of potassium phosphate. The Mo-Sb reagent solution contained (per liter) sulfuric acid, $2.87 \mathrm{~mol}$; ammonium molybdate, $8.1 \mathrm{mmol}$; antimonyl potassium tartrate, $1.5 \mathrm{mmol}$; ascorbic acid, $85.2 \mathrm{mmol}$ (added into the solution just before use).

Concentration of the available phosphorus in the culture media was calculated based on the following equation:

$$
X=\frac{(P \times V 1 \times K)}{V 2}
$$

where $X$ represents available phosphorus in the culture media; $P$, available phosphorus calculated for a reaction mixture; $V 1$, total volume of reaction mixture; $V 2$ volume of culture supernatant added in the reaction mixture; $K$, the dilution ratio used for measuring the absorbance.

\section{Chemotaxonomic Tests}

Biomass for chemotaxonomic studies of the strains was obtained by cultivation in flasks on a rotary shaker $(180 \mathrm{rpm})$ using GYM broth at $28^{\circ} \mathrm{C}$ for 4 days except that cellular fatty acid extraction and analysis were conducted using the cultures harvested from Tryptic soy broth (TSB). The diagnostic isomers of diaminopimelic acid in the whole cell hydrolysates $(4 \mathrm{~N}$ 
$\mathrm{HCl}, 100^{\circ} \mathrm{C}, 15 \mathrm{~h}$ ) of these strains were subjected to thin-layer chromatography on cellulose plates using the solvent system of Schleifer and Kandler (1972). The sugar analysis of whole cell hydrolysates followed procedures described by Staneck and Roberts (1974). Polar lipids were extracted and examined by two-dimensional TLC and identified using previously described procedures (Minnikin et al., 1984). Menaquinones were isolated using the method of Collins et al. (1977) and were analysed by HPLC (Groth et al., 1997). Analysis of the whole cell fatty acid pattern followed the described methods using the MIDI system (Microbial ID, Inc., Newark, Del; Kroppenstedt, 1985; Meier et al., 1993). MIDI Sherlock Version 6.0 and ACTIN1 database were employed for this analysis.

\section{Whole-Genomic Study Genome Sequencing and Assembly}

The whole-genome sequencing was implemented using an Illumina HiSeq 4000 system (Illumina, SanDiego, CA, United States) at the Beijing Genomics Institute (Shenzhen, China). Genomic DNA was sheared randomly to construct three read libraries with length of $300 \mathrm{bp}$ by a Bioruptor ultrasonicator (Diagenode, Denville, NJ, United States) and physico-chemical methods. The paired-end fragment libraries were sequenced according to the Illumina HiSeq 4000 system's protocol. Raw reads of low quality from paired-end sequencing (those with consecutive bases covered by fewer than five reads) were discarded. The sequenced reads were assembled using SOAPdenovo v1.05 software.

\section{Genome Component Prediction}

Gene prediction was performed on the genome assembly by glimmer ${ }^{4}$ with Hidden Markov models. The tRNAscan-SE (Lowe and Eddy, 1997), RNAmmer, and the Rfam databases were employed for sorting of tRNA, rRNA, and sRNAs, respectively. The tandem repeats annotation was obtained using the Tandem Repeat Finder, ${ }^{5}$ and the minisatellite DNA and microsatellite DNA selected based on the number and length of repeat units. The Genomic Island Suite of Tools (GIST) used for genomicis lands analysis ${ }^{6}$ with IslandPath-DIOMB, SIGI-HMM, IslandPicker method. Prophage regions were predicted using the PHAge Search Tool (PHAST) web server ${ }^{7}$ and CRISPR identification using CRISPRFinder.

\section{Gene Annotation}

Rapid Annotation using Subsystem Technology (RAST; Aziz et al., 2008) was applied for annotation of the assembled whole genomic sequences of the family Geodermatophilaceae. The protein sequence of each genome annotated by RAST was used for downstream analysis such as stress-responding genes retrieval, pan-genome analysis, and calculation of AAI and POCP values. For pathway analysis, the predicted proteins

${ }^{4}$ http://www.cbcb.umd.edu/software/glimmer/

${ }^{5}$ http://tandem.bu.edu/trf/trf.html

${ }^{6}$ http://www5.esu.edu/cpsc/bioinfo/software/GIST/

${ }^{7}$ http://phast.wishartlab.com/ sequences were uploaded to KEGG Automatic Annotation Server with "for prokaryotes" and "bidirectional best hit" options. The website of UniProt $^{8}$ was implemented for the validation of stress response genes. Predictions of gene clusters for natural products were performed using antiSMASH (Blin et al., 2019).

\section{Whole Genome Based Taxonomy}

Genomic robust indexes, i.e., ANI (average nucleotide identity), dDDH (digital DNA-DNA hybridisation), AAI (average amino identity), and POCP (percentage of conserved proteins) were calculated for the definition and classification of the novel species of the genus Modestobacter. ANI Calculator (Yoon et al., 2017b), ${ }^{9}$ Genome-to-Genome Distance Calculator (Meier-Kolthoff et al., 2013), ${ }^{10}$ Average Amino acid Identity (Rodriguez-R and Konstantinidis, 2016), ${ }^{11}$ and POCP described by Qin et al. (2014) were used to calculate the ANI, dDDH, AAI, and POCP, respectively.

Bacterial Pan-genome Analysis (BPGA) pipeline was applied for analysis of the genomic diversity of the Modestobacter members. The protein sequences of strains CPCC $205119^{\mathrm{T}}$, CPCC 205215, and CPCC 205251 were annotated by RAST 2.0. The protein sequences of other Modestobacter strains were accessed from NCBI. Pan-genome analysis was performed by BPGA 1.3 using default settings (Chaudhari et al., 2016), and the pan- and core-genome analysis of the Modestobacter spp. was also performed by using the Roary pipeline (Page et al., 2015). A total of 22 protein sequence files annotated from the 22 corresponding strains' whole genome sequences were used to generate orthologous gene/protein clusters (homologous families) by USEARCH clustering tool and construct the phylogenetic tree using the concatenated core genes by BPGA. Except the strain M. lacusdianchii JXJ CY $19^{\mathrm{T}}$, without available genome sequence in the database, all other 22 strains were also included in the 16S rRNA gene phylogenetic tree. Each homologous family was given a conserved value $(\mathrm{CV})$ based on the frequency it occurs in the three genomes. Different $\mathrm{CV}$ reflects the distribution frequency of the homologous gene in these three strains. The larger $\mathrm{CV}$ indicates that the gene is more widely distributed in the strains of the species $M$. deserti sp. nov. and the more conserved the gene family is in the species $M$. deserti. In the pan-genome of the three strains, if the CVs of some homologous families were 3, these homologous families were considered as the part of core genome; those homologous families with the $\mathrm{CV}$ of 2 or 1 were regarded as accessory genes or unique genes, respectively. The core, accessory, unique and exclusively absent genes were retrieved using USEARCH clustering tool. BPGA performed the evolutionary analysis based on concatenated core gene alignments and binary (presence/absence) pan-matrix. Gene matrix was calculated using similarity or dissimilarity in contribution of genes to orthologous gene clusters. For core genome based phylogenetic tree, BPGA first extracted the protein sequences (excluding

\footnotetext{
${ }^{8} \mathrm{https} / / /$ www.uniprot.org/

${ }^{9}$ https://www.ezbiocloud.net/tools/ani

${ }^{10} \mathrm{https} / / /$ ggdc.dsmz.de/

${ }^{11} \mathrm{http}$ //enve-omics.ce.gatech.edu/aai/
} 
paralogs) from 20 random orthologous gene clusters to generate core genome phylogeny tree. BPGA automated multiple sequences alignments using MUSCLE. All alignments were concatenated and a neighbor-joining phylogenetic tree was constructed.

\section{RESULTS AND ANALYSIS}

\section{Isolation and Identification of Modestobacter Strains}

Strains designated as CPCC 205119 ${ }^{\mathrm{T}}$ and CPCC 205215 were isolated from moss-dominated soil crust samples IMB12100 and IMB12108, respectively, and strain CPCC 205251 was acquired from cyanobacteria-dominated soil crust sample CCL12125, collected from Shapotou NDER in Tengger Desert, China.

The complete 16S rRNA gene sequences of strains CPCC $205119^{\mathrm{T}}(1,529 \mathrm{bp})$, CPCC 205215 (1,529bp), and CPCC 205251 $(1,529 \mathrm{bp})$ were obtained. Pairwise alignment indicated that these three newly isolated strains contained almost identical $16 S$ rRNA genes. BLAST search results showed that they exhibited the highest similarities with the validly described species of the genus Modestobacter, i.e., M. lapidis DSM $100206^{\mathrm{T}}$ (97.3\%), M. multiseptatus DSM $44406^{\mathrm{T}}$ (97.3\%), and other type strains of the genus Modestobacter $(<97.0 \%)$. These similarity values were all lower than $98.65 \%$, which was proposed by Kim et al. as the threshold for differentiating two genic species according to the 16S rRNA gene similarity (Kim et al., 2014). In the Neighbour-Joining phylogenetic tree based on the $16 \mathrm{~S}$ rRNA gene sequences, strains CPCC $205119^{\mathrm{T}}$, CPCC 205215, and CPCC 205251 formed a stable subclade next to the subclade containing M. lapidis DSM $100206^{\mathrm{T}}$ and M. multiseptatus DSM $44406^{\mathrm{T}}$ in the genus of Modestobacter lineage, within the family Geodermatophilaceae (Figure 1), which showed almost the same case in maximum-parsimony, maximum-likelihood trees. These results indicated these three strains could be affiliated to the genus of Modestobacter as a distinct species.

\section{Genome-Based Classification}

Assembly sequences for the draft genomes of CPCC $205119^{\mathrm{T}}$, CPCC 205215, and CPCC 205251 were deposited in GenBank with the accession number JAAGWK000000000, WGGQ00000000, and JAABOZ000000000. The detailed genome repertoires were given in the supplementary materials (Supplementary Table S1). In the phylogenetic tree based on the concatenated core genes, strains CPCC $205119^{\mathrm{T}}$, CPCC 205215, and CPCC 205251 clustered in a unique branch in the lineage of the genus Modestobacter, with the closest evolutionary distance with the branch formed by $M$. lapidis DSM $100206^{\mathrm{T}}$ and $M$. multiseptatus DSM 44402 (Supplementary Figure S1). The dDDH values between strain CPCC $205119^{\mathrm{T}}$ and their closest phylogenic neighbors ranged in $20.4-22.7 \%$, which was far below than the cut-off value (70\%) used to classify bacterial strains of the same species (Auch et al., 2010); the ANI values between strain CPCC $205119^{\mathrm{T}}$ and their closest phylogenic neighbors ranged in 79.5-79.7\%, which were also much lower than the threshold for bacterial species delineation (95-96\%; Kim et al., 2014); the AAI values between strain CPCC $205119^{\mathrm{T}}$ and their closest phylogenic neighbors ranged in 71.1-71.8\%, which were also much lower than the threshold for bacterial species delineation ( 90\%; Rodriguez-R and Konstantinidis, 2014); the POCP values between strain CPCC $205119^{\mathrm{T}}$ and their closest phylogenic neighbors ranged in 53.4-58.5\%, which were all higher than threshold for bacterial genus delineation (50\%), while lower than the threshold for bacterial species delineation (70\%; Qin et al., 2014; Table 1). While the pairwise values of $\mathrm{dDDH}$, ANI and AAI and POCP among these three strains readily confirmed to classify these three strains as one species (Supplementary Table S2). Therefore, the above results strongly supported the proposal that the three strains represent a single novel species ( $M$. deserti sp. nov.) of the genus Modestobacter. The calculated $\mathrm{G}+\mathrm{C}$ contents of these strains were in the range of $74.6-74.7 \%$.

\section{Genes Associated With Stress Response}

The whole genome of strains CPCC $205119^{\mathrm{T}}$, CPCC 205215, and CPCC 205251 contained 4,480, 4,443, and 4,523 genes, respectively (Supplementary Table S1). The strains M. lapidis DSM $100206^{\mathrm{T}}$ isolated from building rock surface and $M$. multisptatus DSM 44402 isolated from Antarctica's dry and cold Valley composed of 4,366 and 6,094 genes, respectively, which were included as reference. The putative stress-responding related genes were retrieved in the whole genome DNA annotation results (Figure 2). The heat shock response related genes (clpB, dnaK, dnaJ, grpE, and $h r c A$ gene; Li et al., 2011), the cold shock response related genes ( $\operatorname{csp} A, \operatorname{csp} C$; Essoussi et al., 2010), osmotic stress related genes (aglF, aglG, ots $A$, otsB, treS, treY, treZ, opuAA, opuAB, opuAC, and opuD; Kempf and Bremer, 1995; Pan et al., 2008; Reina-Bueno et al., 2012), oxidative stress-related genes (bcp, btuE, efeB, katA, katE, katG, sodN and soxR; Martindale and Holbrook, 2002), carbon source starvation stress-related genes (csrA; Romeo et al., 1993; Romeo, 1998), UV-radiation-resistant genes (uvrA, uvrB, uvrC, and uvrD; Long et al., 2020), DNA repair related genes (recA, $r e c F, r e c G, \operatorname{recN}, \operatorname{recO}, \operatorname{rec} Q$, and recR; Hickson, 2003; Manthei et al., 2015), heat-resistant esterase coding genes [esterase (EC 3.1.1.X) coding genes; Essoussi et al., 2010; Jaouani et al., 2012], alkaline phosphatase genes ( $p h o A / p h o D)$, pyrophosphatase coding gene $(p p a)$, and phytase coding gene ( $p h y C$; Pasamontes et al., 1997), phosphate starvation-inducible protein coding gene $(p h o H)$, phosphate transport-related genes ( $p h o U$, phnC, phnD, phnE, phoB, phoH, phoP, phoR, pitH, ppk, pstA, pstB, pst $C$, and pstS; Song et al., 2020), carbon monoxide assimilationrelated genes ( $\operatorname{cox} L S M$ gene cluster, $\operatorname{cox} D$ and $\operatorname{coxE}$; Lorite et al., 2000), rhodopsin-encoding genes (bop; Shand and Betlach, 1994), arsenate resistance genes (arsC; Chouaia et al., 2012), copper resistance related genes (cop), various metal resistance genes $(c z c D)$, DNA inducible enzyme gene $(d n a G)$, thioredoxin reductase gene $(t r x)$, and mitomycin free radical oxidase gene ( $m c r A$; Normand et al., 2012) were predicted from all or partial of these strains. A total of 99 copies, 100 copies, 101 copies, 99 copies, and 111 copies of stress response related genes accounted for $2.21,2.25,2.23,2.26$, and $1.82 \%$, respectively, 
in their whole genomes. These data showed stress-responding related genes seemed richer in the microorganisms inhabited in deserts (these three newly isolates) and the rock surface (M. lapidis DSM 100206 ${ }^{\mathrm{T}}$ ) than that in Antarctica's Valley (M. multisptatus DSM 44402).

\section{Pan-genome Analysis of the Species Modestobacter deserti}

A total of 13,532 protein-coding genes (Table 2) were sorted from the genomes of these three strains of the species $M$. deserti, which were divided into 4,592 homologous families by cluster analysis. Histograms were constructed according to different CVs (Figure 3A). Among them, there were a total of 4,282 core genes commonly shared by these three strains $(\mathrm{CV}=3)$, accounting for about $93.2 \%$ of the total number of homologous gene families. The accessory genes (188 genes; $\mathrm{CV}=2$ ) accounted for about $4.1 \%$ of the homologous gene families in the newly proposed species. The proportion of the unique genes (122 genes; $\quad \mathrm{CV}=1)$ was about $2.7 \%$ (Supplementary Figure S2).

The relationship between the pan-genome size and the number of genomes of the species, and the relationship between the number of core genes and the number of genomes were deduced (Figure 3B) by using all the protein sequences extracted from these three strains of the species $M$. deserti. The functional relationship between pan-genome size $\left(f_{\mathrm{pan}}\right)$ and the number of genomes $(n)$ was obtained by fitting, as follows:

$$
\mathrm{f}_{\mathrm{pan}}(\mathrm{n})=4450.13 \times n^{0.0306539}
$$

Meanwhile, the functional relationship between the number of core genes $\left(f_{\text {core }}\right)$ and the number of genomes $(n)$ was obtained by fitting, as follows:

$$
\mathrm{f}_{\text {core }}(\mathrm{n})=4534 \times \mathrm{e}^{-0.0202158 n}
$$

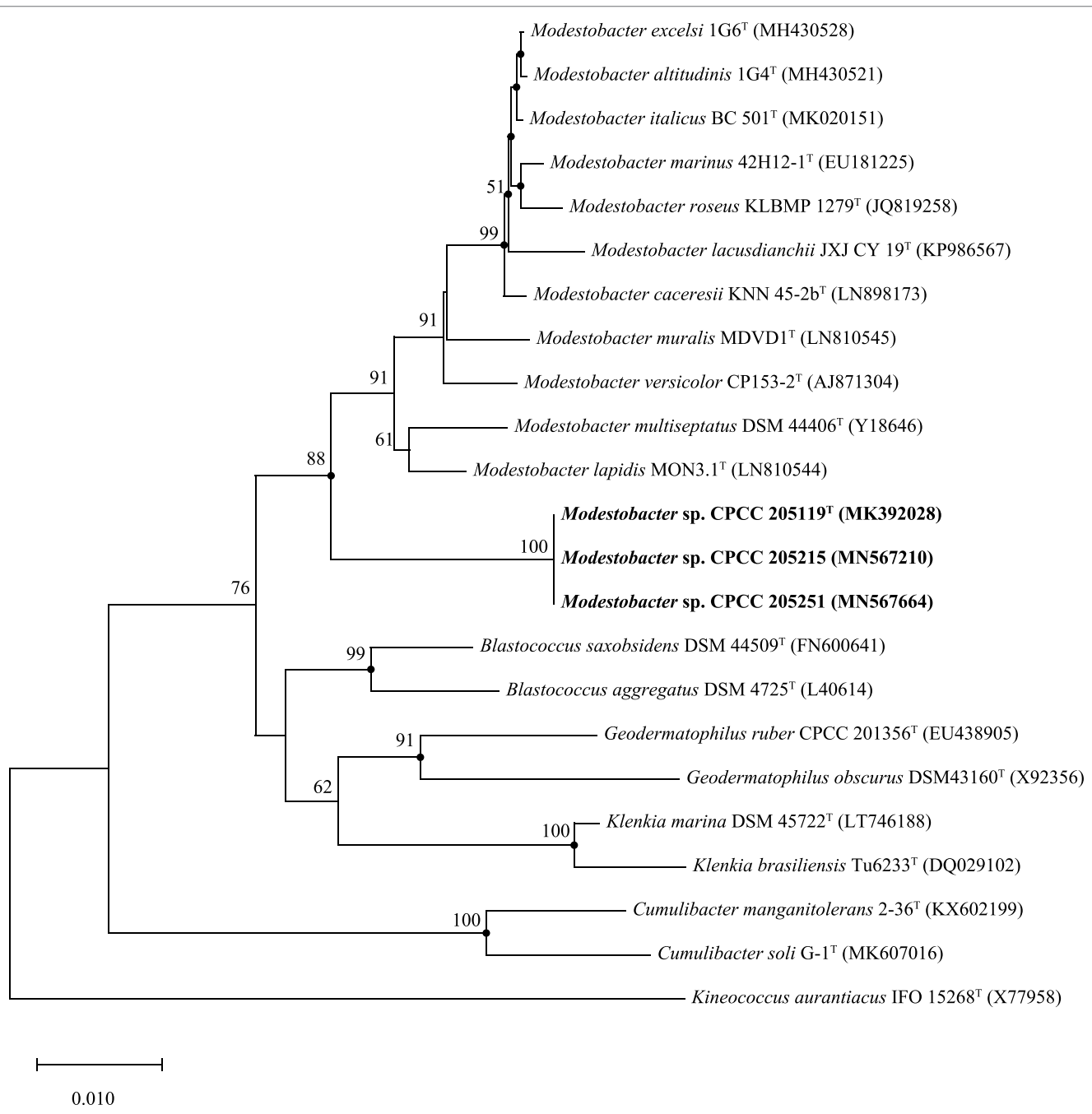

FIGURE 1 | Neighbour-joining tree based on 16S rRNA gene sequences showing the relationship of the strains CPCC 205119 representatives of the family Geodermatophilaceae. Filled circles indicate that the corresponding nodes were also recovered in the trees generated with the maximumlikelihood and maximum-parsimony methods. Bootstrap values (>50\%) are shown as percentages of 1,000 replicates. Bar, 1 nt substitutions per $100 \mathrm{nt}$. 
TABLE 1 | The values of ANI, dDDH, AAI, and POCP of the whole genome DNA assembly sequences between the strain CPCC $205119^{\top}$ and the closest phylogenic neighbours.

\begin{tabular}{lcccc}
\hline & \multicolumn{4}{c}{ CPCC 205119 } \\
\cline { 2 - 5 } & ANI (\%) & dDDH (\%) & AAI (\%) & POCP (\%) \\
\hline $\begin{array}{l}\text { Modestobacter } \\
\text { lapidis DSM }\end{array}$ & 79.7 & 22.7 & 71.8 & 58.5 \\
$\begin{array}{l}100206 \\
\text { Modestobacter } \\
\text { multiseptatus }\end{array}$ & 79.5 & 20.4 & 71.1 & 53.4 \\
DSM 44402 & & & & \\
\hline
\end{tabular}

$A N I$, values of average nucleotide identity; $d D D H$, digital DNA-DNA hybridization; AAI, average amino acid identity; POCP, percentage of conserved proteins.

TABLE 2 | The pan-genome profile of the species Modestobacter deserti sp. nov.

\begin{tabular}{|c|c|c|c|c|c|}
\hline $\begin{array}{l}\text { Genome } \\
\text { number }\end{array}$ & $\begin{array}{l}\text { Organism } \\
\text { name }\end{array}$ & $\begin{array}{l}\text { No. of } \\
\text { core } \\
\text { genes }\end{array}$ & $\begin{array}{l}\text { No. of } \\
\text { accessory } \\
\text { genes }\end{array}$ & $\begin{array}{c}\text { No. of } \\
\text { unique } \\
\text { genes }\end{array}$ & $\begin{array}{c}\text { No. of } \\
\text { exclusively } \\
\text { absent } \\
\text { genes }\end{array}$ \\
\hline 1 & $\begin{array}{l}\text { M. deserti } \\
\text { CPCC } \\
205119^{\top}\end{array}$ & 4,282 & 158 & 42 & 30 \\
\hline 2 & $\begin{array}{l}\text { M. deserti } \\
\text { CPCC } \\
205215\end{array}$ & 4,282 & 55 & 45 & 133 \\
\hline 3 & $\begin{array}{l}\text { M. deserti } \\
\text { CPCC } \\
205251\end{array}$ & 4,282 & 163 & 35 & 25 \\
\hline
\end{tabular}

It could be observed from the pan-genome fitting curve in the Figure 3B that, with the increasing number of sequenced genomes, the pan-genome size tended to a plateau. Accordingly, it could be inferred that the pan-genome of the novel species $M$. deserti was almost closed.

Out of 4,592 genes (clusters), BPGA could map 2,508 (54.6\%) to KEGG (Kyoto Encyclopedia of Genes and Genomes) pathways, i.e., core genes $(2,457,98.0 \%)$, accessory genes $(47,1.9 \%)$ and unique genes $(4,0.1 \%)$. Having filtered some KEGG pathway related to eukaryotes, we obtained an overview on the metabolic pathway corresponding to the gene(s) in the pan-genome of the species $M$. deserti. A large number of core genes $(2,305$, $15.6 \%)$ were involved in carbohydrate metabolism, amino acid metabolism (14.3\%), some other elementary metabolism (biosynthesis of amino acids, 4.9\%; carbon metabolism, 4.6\%; fatty acid metabolism, 1.8\%; 2-oxocarboxylic acid metabolism, $1.1 \%$ and degradation of aromatic compounds, $0.5 \% ; 12.8 \%$ ), energy metabolism (6.8\%), metabolism of cofactors and vitamins (5.6\%), lipid metabolism (5.3\%), nucleotide metabolism (5.3\%), and membrane transport (5.1\%). Accessory and unique genes appeared to be enriched in membrane transport, carbohydrate metabolism, as well as metabolism of cofactors and vitamins. Among the accessory genes (41), the major portion of genes seemed related to membrane transport (19.5\%), metabolism of cofactors and vitamins (14.6\%), carbohydrate metabolism (12.2\%), amino acid metabolism (9.8\%), some other elementary metabolism (biosynthesis of amino acids, 4.9\%; carbon metabolism, $2.4 \%$ and fatty acid metabolism, $2.4 \%$; $9.8 \%$ ), signal transduction (9.8\%), signal transduction (9.8\%). Unique genes (4) seemed to be mainly enriched in carbohydrate metabolism (75\%), and carbon metabolism (25\%; Figure 4).

\section{Phenotypic Properties}

\section{Morphological and Physiological Characteristics}

Orange to red colored colonies with a maximum diameter of $1.1 \mathrm{~mm}$ were opaque, convex and irregular circle on ISP 2, GYM, TSA, $\mathrm{R}_{2} \mathrm{~A}, \mathrm{NA}$, and PYG agar after incubation for $72 \mathrm{~h}$ at $28^{\circ} \mathrm{C}$. No diffusible pigments were observed on any tested media. Cells of strains CPCC 205119 , CPCC 205215, and CPCC 205251 were aerobic, Gram-staining-positive, non-spore-forming, cocci (diameter of $0.5-0.8 \mu \mathrm{m})$ and/or short rods $(0.5-0.6 \mu \mathrm{m}$ in width and $0.8-1.1 \mu \mathrm{m}$ in length), motile with polar flagella. Bud-like structure was observed for some cells (Figure 5). These three strains grew well on ISP 2 agar and GYM agar, moderate growth occurred on and $\mathrm{R}_{2} \mathrm{~A}$ agar, TSA, NA and PYG media. Growth of these strains was observed at $10-37^{\circ} \mathrm{C}, \mathrm{pH} 6.0-11.0$, in ISP 2 medium with the presence of $0-3 \%(w / v) \mathrm{NaCl}$. The optimum growth occurred at $28-32^{\circ} \mathrm{C}, \mathrm{pH} 6.0-8.0$, with the absence of $\mathrm{NaCl}$. The catalase, oxidase and phosphate solubilizing activity of these strains were positive. None of these strains can hydrolyze gelatin, CM-cellulose (carboxymethyl cellulose), urea and starch. Nitrate was not reduced and $\mathrm{H}_{2} \mathrm{~S}$ was not produced.

Detailed physiological and biochemical characteristics of these strains from Biolog GEN III, PM3B, and PM4A Microplates, and API $50 \mathrm{CH}$ and API ZYM test kits are given in the description of the species and in the supplementary materials as Supplementary Table S3.

In the liquid culture assay, strains CPCC $205119^{\mathrm{T}}$, CPCC 205215, and CPCC 205251 could solubilize tricalcium phosphate $\left[\mathrm{Ca}_{3}\left(\mathrm{PO}_{4}\right)_{2}\right]$ and phytin with a detection of additional available phosphorus of $(4.72 \pm 0.34) \mathrm{mg} / \mathrm{L}$ and $(36.78 \pm 1.75) \mathrm{mg} / \mathrm{L}$, respectively.

\section{Chemotaxonomic Characteristics}

These three isolates were found to contain alanine, glutamic acid, glycine, and meso-diaminopimelic (meso-DAP) in the cell wall. Whole-cell hydrolysates yielded arabinose, glucose and ribose. The cellular polar lipids contained DPG, PE, PG, PI and PIM, PME as well as small amounts of unidentified phospholipid (UPL) and aminophospholipid (APL; Supplementary Figure S3). In the menaquinones extraction, tetrahydrogenated menaquinones with nine isoprene units as the predominant isoprenologue, i.e., MK- $9\left(\mathrm{H}_{4}\right)(78.8-82.3 \%$ of total menaquinone composition) with minor amounts of MK-8 $\left(\mathrm{H}_{4}\right)(17.7-21.2 \%)$; The cellular fatty acids were $\mathrm{C}_{18: 1} \omega 9 \mathrm{c}$ (18.9-29.7\%), iso- $\mathrm{C}_{16: 0}(11.2-20.9 \%), \mathrm{C}_{16: 0}(6.7-11.0 \%), \mathrm{C}_{17: 1} \omega 8 c$ $(4.2-11.8 \%), \mathrm{C}_{16: 1} \omega 7 c$ (6.6-9.0\%), iso- $\mathrm{C}_{15: 0}(6.1-8.0 \%), \mathrm{C}_{18: 0}$ (4.3-5.8\%; Supplementary Table S4).

\section{Taxonomic Study Conclusion}

The 16S rRNA gene sequence comparison results and the phylogenic analysis suggest that strains CPCC $205119^{\mathrm{T}}$, CPCC 205215, and CPCC 205251 represent a single novel species of the genus 


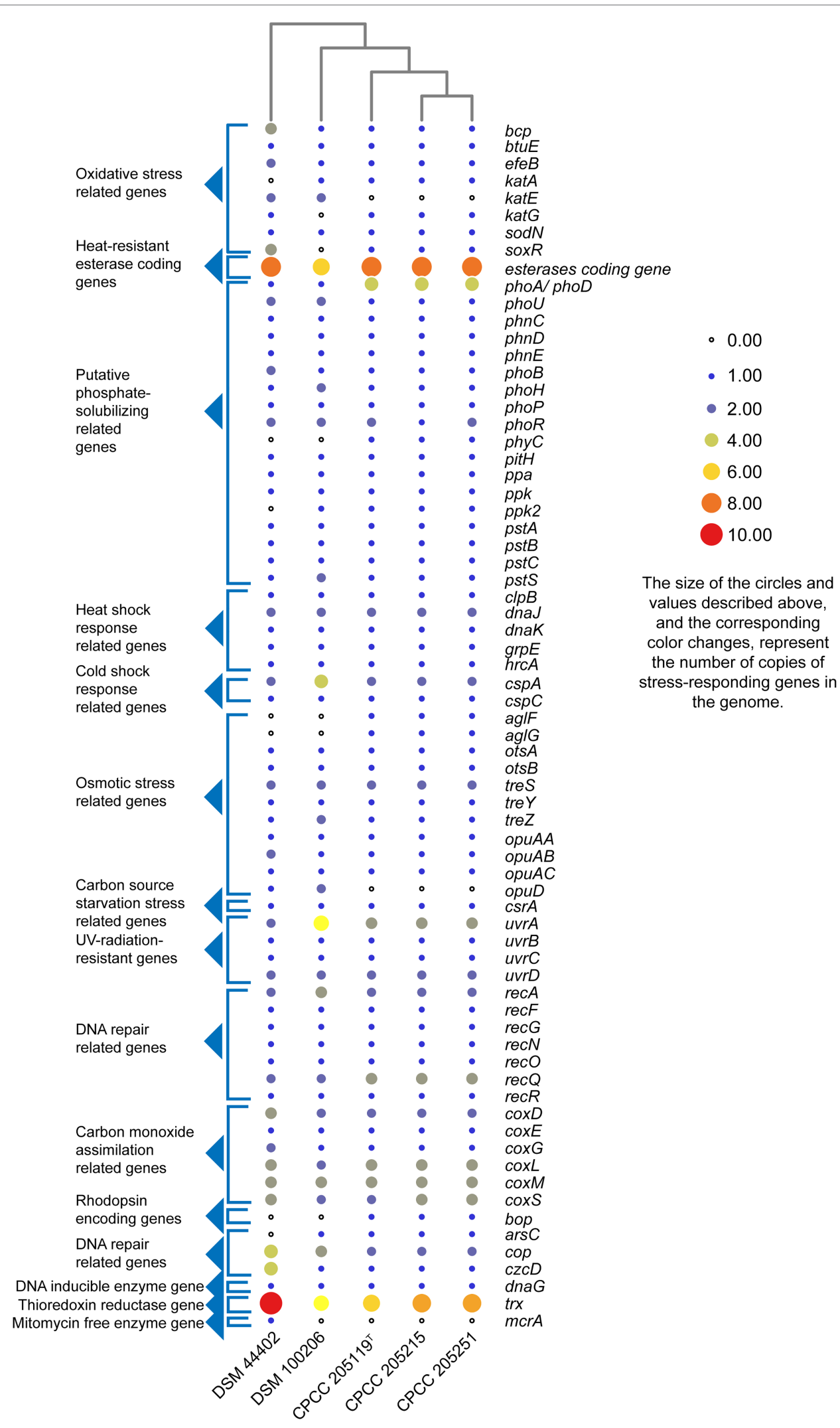

FIGURE 2 | Heatmap of putative stress-responding genes predicted in the genomes of strains CPCC 205119', CPCC 205215, CPCC 205251, and their closest phylogenic neighbors according to the copy number of the genes from the Rapid Annotation using Subsystem Technology (RAST) annotation. 
Modestobacter. This proposal was well approved by the whole genome research repertoires including ANI, dDDH, AAI, POCP, and the pan-genome phylogenic analysis. The phenotypic properties of strains CPCC 205119 ${ }^{\mathrm{T}}$, CPCC 205215, and CPCC 205251, such as the assimilation of carbon sources and chemotaxonomic characteristics (Table 3) well supported the classification these three stains as one so far unknown species in the genus Modestobacter. Therefore, based on the above phenotypic and genotypic data, we suggested to establish a new species in the genus Modestobacter, for which the name $M$. deserti sp. nov. was proposed, with strain CPCC $205119^{\mathrm{T}}$ as the type strain.

\section{Description of Modestobacter deserti sp. nov.}

Modestobacter deserti sp. nov. (de.ser'ti. L. gen. n. deserti of a desert, where the organisms were acquired).
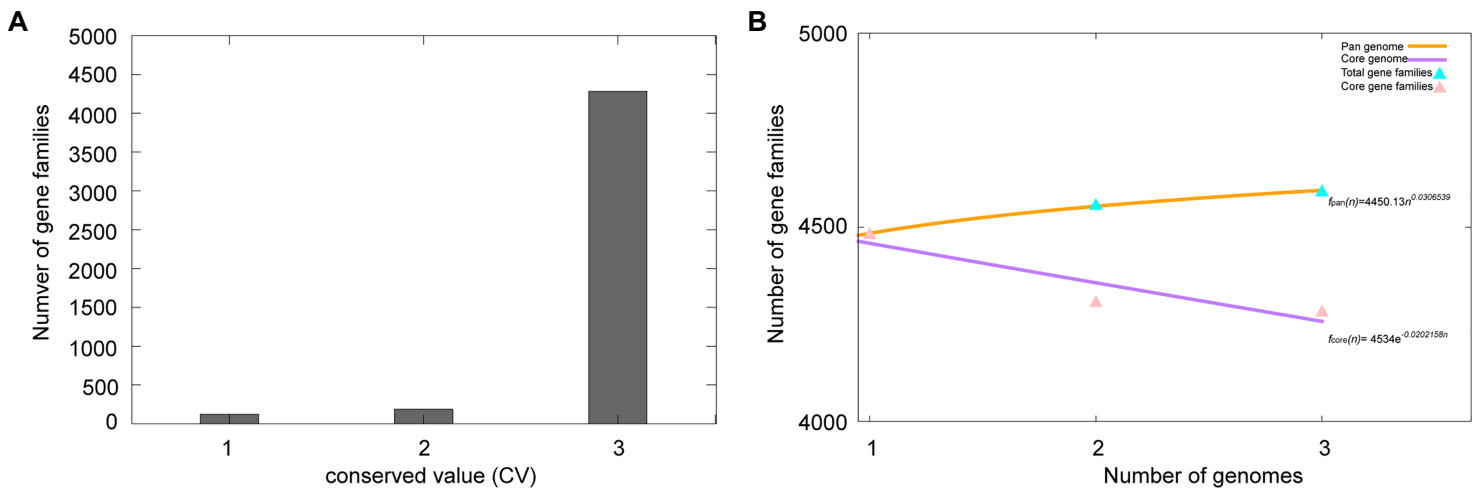

FIGURE 3 | Overview of the pan-genome generated by Bacterial Pan-genome Analysis (BPGA) using three strains of the species Modestobacter deserti. (A) The gene family frequency spectrum. (B) The pan genome profile trends of the species Modestobacter deserti obtained using clustering tools USEARCH.

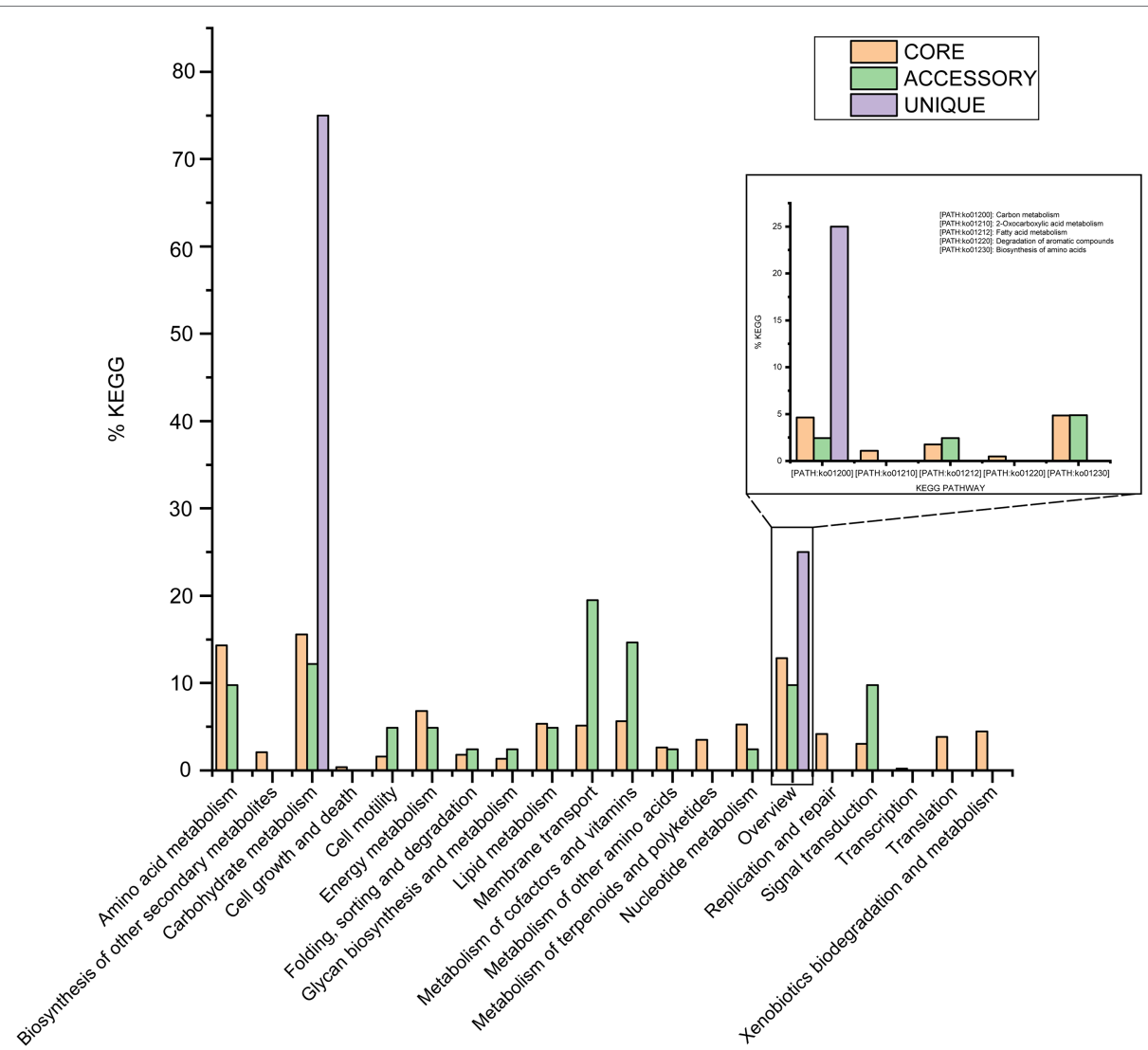

FIGURE 4 | The assigned metabolic pathways associated with the core, accessory, and unique genes among the species Modestobacter deserti from the KEGG database. 

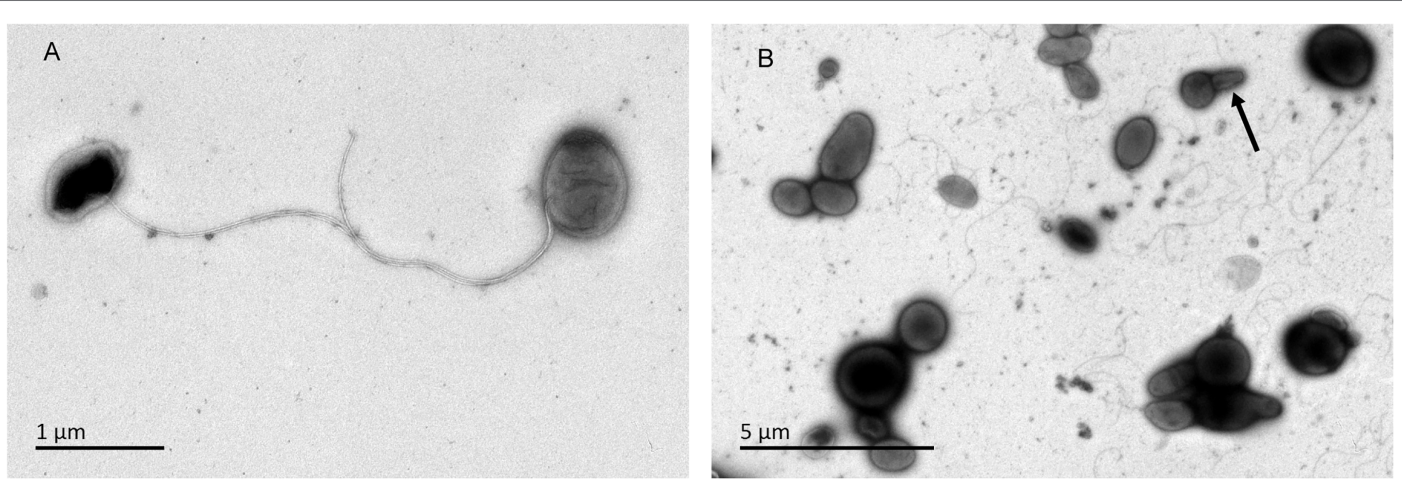

FIGURE 5 | Transmission electron micrograph of strain CPCC $205119^{\top}$ grown on GYM semi-solid medium (0.3\% agar) for 7 days at $28^{\circ} \mathrm{C}$. Bar, $2 \mu \mathrm{m}$. (A) Showing the flagella; (B) arrow, indicating the bud-like structure.

TABLE 3 | Differentiating phenotypic characteristics of strain CPCC 205119', CPCC 205215, CPCC 205251, and their phylogenetically related species of the genus Modestobacter.

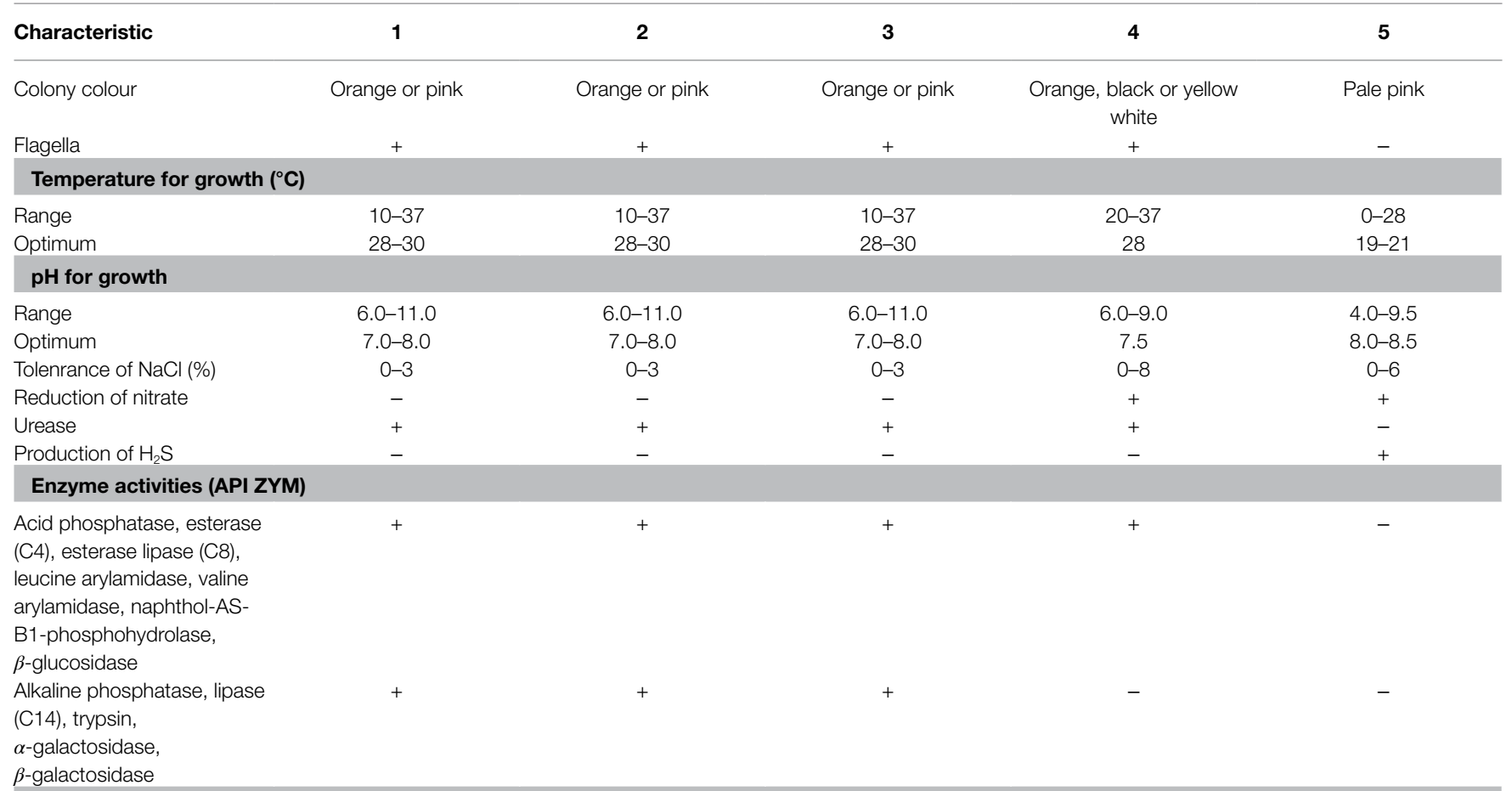

\section{Utilization of (Biolog GEN III)}

\section{Dextrin}

d-fructose-6- $\mathrm{PO}_{4}$, inosine

d-fucose, I-rhamnose

d-galactose, d-mannose,

$\mathrm{d}$-salicin, $\alpha$-d-lactose

d-glucose-6- $\mathrm{PO}_{4}$

d-melibiose, gentiobiose

d-rnaffinose

Glucuronamide

$N$-acetyl-d-glucosamine,

$N$-acetyl- $\beta$-d-mannosamine

d-arabitol, d-mannitol

d-sorbitol

Glycerol

myo-inositol

+
+
-
+
+
+
-
-
-
-
-
+
+

$\begin{array}{ll}+ & + \\ - & \\ - & \\ + & \\ - & - \\ - & - \\ - & - \\ + & - \\ - & - \\ - & - \\ + & +\end{array}$

+
-
-
+
-
-
-
-
-
-
-
+
+

$\begin{array}{ll}+ & - \\ + & + \\ - & + \\ - & + \\ + & - \\ + & - \\ + & + \\ + & - \\ - & + \\ & + \\ - & + \\ + & - \\ - & + \\ - & +\end{array}$


TABLE 3 | Continued

\begin{tabular}{|c|c|c|c|c|c|}
\hline Characteristic & 1 & 2 & 3 & 4 & 5 \\
\hline d-serine & - & - & - & + & - \\
\hline $\begin{array}{l}\text { I-alanine, I-arginine, } \\
\text { I-histidine }\end{array}$ & - & - & - & - & + \\
\hline I-glutamic acid & + & + & + & - & + \\
\hline Gelatin & + & + & + & + & - \\
\hline Acetoacetic acid & - & + & + & + & + \\
\hline $\begin{array}{l}\text { Bromo-succinic acid, d- } \\
\text { malic acid, propionic acid }\end{array}$ & + & + & + & + & - \\
\hline $\begin{array}{l}\text { Citric acid, d-galacturonic } \\
\text { acid, I-pyroglutamic acid, } \\
\text { p-hydroxy-phenylacetic acid }\end{array}$ & - & - & - & + & - \\
\hline $\begin{array}{l}\text { d-saccharic acid, I-lactic } \\
\text { acid, } \beta \text {-Hydroxy-D,I-butyric } \\
\text { acid }\end{array}$ & - & - & - & - & + \\
\hline $\begin{array}{l}\text { d-aspartic acid, mucic acid, } \\
\text { quinic acid, } \alpha \text {-keto-glutaric } \\
\text { acid }\end{array}$ & - & - & - & + & + \\
\hline d-gluconic acid & + & - & - & - & + \\
\hline Formic acid & - & + & - & - & - \\
\hline $\begin{array}{l}\text { Methyl pyruvate, } \\
\alpha \text {-hydroxy-butyric acid }\end{array}$ & - & + & + & - & - \\
\hline Pectin & - & + & + & + & - \\
\hline Tween 40 & + & + & + & - & - \\
\hline DNA G $+\mathrm{C}$ content $(\%)$ & 74.6 & 74.7 & 74.7 & 72 & 69.9 \\
\hline Phospholipids profile & $\begin{array}{l}\text { APL1, APL2, DPG, PE, } \\
\text { PG, PI, PIM, PME, UPL }\end{array}$ & $\begin{array}{l}\text { APL1, APL2, DPG, PE, } \\
\text { PG, PI, PIM, PME, UPL }\end{array}$ & $\begin{array}{l}\text { APL1, APL2, DPG, PE, } \\
\text { PG, PI, PIM, PME, UPL }\end{array}$ & DPG, PE, PG, PI, PIM & DPG, PE, PG, PI \\
\hline Major Menaquinone(s) & $\mathrm{MK}-9\left(\mathrm{H}_{4}\right)$ & $\mathrm{MK}-9\left(\mathrm{H}_{4}\right)$ & $\mathrm{MK}-9\left(\mathrm{H}_{4}\right)$ & $\mathrm{MK}-9\left(\mathrm{H}_{4}\right)$ & $\begin{array}{l}\text { MK-9 }\left(\mathrm{H}_{4}\right), M K-8\left(\mathrm{H}_{4}\right) \text { and } \\
\left.\text { MK-9( } \mathrm{H}_{6}\right)\end{array}$ \\
\hline $\begin{array}{l}\text { Fatty acids components } \\
(>5 \%)\end{array}$ & $\begin{array}{l}\mathrm{C}_{18: 1} \omega 9 c, \text { iso- } \mathrm{C}_{16: 0}, \mathrm{C}_{16: 0} \\
\text { iso- } \mathrm{C}_{15: 0}, \mathrm{C}_{16: 1} \omega 7 c, \mathrm{C}_{18: 0}\end{array}$ & $\begin{array}{l}C_{18: 1} \omega 9 c, \text { iso- } C_{16: 0}, C_{17: 1} \\
\omega 8 c, \text { iso- } C_{15: 0}, C_{16: 1} \omega 7 c, \\
C_{16: 0}\end{array}$ & $\begin{array}{l}\mathrm{C}_{18: 1} \omega 9 c, \mathrm{C}_{17: 1} \omega 8 c \\
\text { iso- } \mathrm{C}_{16: 0}, \mathrm{C}_{16: 1} \omega 7 c, \mathrm{C}_{16: 0}, \\
\text { iso- } \mathrm{C}_{15: 0}, \mathrm{C}_{18: 0}\end{array}$ & $\begin{array}{l}\text { iso- } C_{16: 0}, \text { iso- } C_{15: 0}, C_{16: 1} \\
\omega 9 c, C_{16: 0}, C_{17: 1} \omega 9 c\end{array}$ & $\begin{array}{l}\text { iso- } \mathrm{C}_{16: 0}, \mathrm{C}_{18: 1} \text {, } \\
\text { anteiso- } \mathrm{C}_{17: 0} \text {, cycle- } \mathrm{C}_{19: 0}\end{array}$ \\
\hline Isolation source & $\begin{array}{l}\text { Cyanobacteria- } \\
\text { dominated soil crusts of } \\
\text { the Tengger Desert, } \\
\text { China }\end{array}$ & $\begin{array}{l}\text { Moss-dominated soil } \\
\text { crusts of the Tengger } \\
\text { Desert, China }\end{array}$ & $\begin{array}{l}\text { Cyanobacteria- } \\
\text { dominated soil crusts of } \\
\text { the Tengger Desert, } \\
\text { China }\end{array}$ & $\begin{array}{l}\text { Surface of deteriorated } \\
\text { sandstone of a historic } \\
\text { building, Spain }\end{array}$ & $\begin{array}{l}\text { Soils from Linnaeus } \\
\text { Terrace, Antarctica }\end{array}$ \\
\hline
\end{tabular}

1. CPCC 205119' (data from this study); 2, CPCC 205215 (data from this study); 3, CPCC 205251 (data from this study); 4, M. lapidis DSM 100206 (Trujillo et al., 2015); 5, M. multiseptatus DSM 44406 ${ }^{T}$ (Golińska et al., 2020). All strains are Gram-reaction-positive, positive for motility, catalase and oxidase; contain meso-diaminopimelic in the cell wall and arabinose, glucose and ribose in the whole-cell hydrolysis. In API ZYM kits, all strains are positive for $\alpha$-chymotrypsin, $\alpha$-glucosidase and cystine arylamidase, negative for $\alpha$ fucosidase, $\alpha$-galactosidase, $\alpha$-Mannosidase, $N$-acetyl- $\beta$-glucosaminidase and $\beta$-glucuronidase. In Biolog GEN III (MicroPlate), all strains are positive for acetic acid, $\alpha$ - $\alpha$-glucose, $\alpha$-keto-butyric acid, $d$-cellobiose, $d$-fructose, $d$-maltose, $d$-trehalose, $d$-turanose, I-aspartic acid, I-malic acid, and sucrose assimilation; negative for the utilization of 3-methyl glucose, acetoacetic acid, $d$-glucuronic acid, $d$-lactic acid methyl ester, $d$-serine, formic acid, glycyl-I-proline, I-fucose, I-galactonic acid lactone, I-serine, methyl pyruvate, N-acetylneuraminic acid, $N$-acetyl-d-galactosamine, stachyose, $\beta$-methyl-d-glucoside and $\gamma$-amino-butryric acid. DPG, diphosphatidylglycerol; PE, phosphatidylethanolamine; PME, phosphatidylmethylethanolamine; PG, phosphatidylglycerol; PI, phosphatidylinositol; PIM, phosphatidylinositol mannoside; APL, aminophospholipid; UPL, unidentified phospholipid. + , Positive; -, negative.

Cells are aerobic, Gram-staining-positive, cocci- to rod-shaped, motile, and non-sporing actinobacterium. The colonies are irregular, opaque, orange-red on most tested media. Grows at $10-37^{\circ} \mathrm{C}$ and $\mathrm{pH} 6.0-11.0$, with optima at $28-30^{\circ} \mathrm{C}$ and $\mathrm{pH}$ $7.0-8.0$, respectively. Grows in $\mathrm{NaCl}$ at concentrations up to not more than $3 \%$. The activity of oxidase and catalase is positive. The production of $\mathrm{H}_{2} \mathrm{~S}$, indole and melanin, hydrolysis of gelatin, starch, and cellulose are negative. Cells are positive for acid phosphatase, alkaline phosphatase, cystine arylamidase, esterase lipase (C8), esterase (C4), leucine arylamidase, lipase (C14), naphthol-AS-B1-phosphohydrolase, trypsin, valine arylamidase, $\alpha$-glucosidase, $\beta$-glucosidase, $\beta$-galactosidase, and weekly positive for $\alpha$-chymotrypsin, $\alpha$-galactosidase in API ZYM strip. Acetic acid, bromo-succinic acid, D-cellobiose, Dextrin, D-fructose, D-galactose, D-malic acid, D-maltose, D-mannose, D-salicin, D-trehalose, D-turanose, gelatin, glycerol,
L-aspartic acid, L-glutamic acid, L-malic acid, propionic acid, sucrose, Tween 40, $\alpha$-D-glucose, $\alpha$-D-lactose, and $\alpha$-keto-butyric acid can be utilized as sole carbon sources in Biolog GEN III Micro-Plates. Acid is produced from esculin ferric citrate and potassium 5-ketogluconate. Cell wall contains alanine, glutamic acid, glycine and meso-diaminopimelic as diagnostic amino acids. The whole-cell hydrolysis contains arabinose, galactose, ribose and traces of glucose. The cellular polar lipid system includes DPG, PE, PG, PI, and PIM, as well as small amount of APL. The predominant respiratory quinone is MK- $9\left(\mathrm{H}_{4}\right)$, with minor of MK- $8\left(\mathrm{H}_{4}\right)$. The major fatty acids are $\mathrm{C}_{18: 1} \omega 9 c$, iso- $\mathrm{C}_{16: 0}, \mathrm{C}_{16: 0}$, iso- $\mathrm{C}_{15: 0}$, and $\mathrm{C}_{16: 1} \omega 7 c$. The $\mathrm{G}+\mathrm{C}$ content of the genomic DNA is $74.7 \%$. The type strain is CPCC $205119^{\mathrm{T}}\left(=\mathrm{I} 12 \mathrm{~A}-02624^{\mathrm{T}}=\right.$ NBRC $113528^{\mathrm{T}}=$ KCTC $\left.49201^{\mathrm{T}}\right)$, isolated from the moss-dominated soil crust from the Shapotou NDER located in Tengger Desert situated at the Ningxia Hui 
Autonomous Region, the north of China. The assembly sequences for the draft genome of CPCC $205119^{\mathrm{T}}$ has been deposited in GenBank with the accession number JAAGWK000000000.

\section{DISCUSSION}

Based on the genomic information, we summarized genetic characteristics of the novel species $M$. deserti sp. nov. accommodating three isolates from the desert microbiological soil crusts. The detailed phenotypic properties illustrated the abilities of these strains to adapt to environmental stress.

In core genome of the species $M$. deserti, 37 gene clusters (1.6\%) were mapped to bacterial chemotaxis (ko02030, pathway number in KEGG Orthology) and flagellar assembly (ko02040) pathway which was related to cell motility (KO09142, KEGG Orthology number). These gene clusters, including chemotaxis family related genes cheA, cheB, cheR, cheW, cheY, mcp, motA, $m o t B, r b s B$, tar, and tap, flagellar basal-body rod protein coding genes $f l g B$ and $f l g C$, flagellar basal-body rod modification protein coding gene $f l g D$, flagellar hook protein coding genes $f l g E$ and flgL, flagellar biosynthesis protein coding genes $f h A, f l h B, f l i P$, $f l i Q$, and $f l i R$, RNA polymerase sigma factor for flagellar operon coding gene $f l i A$, flagellin coding gene $f l i C$, flagellar hook-basal body complex protein coding gene fliE, flagellar M-ring protein coding gene fliF, flagellar motor switch protein coding genes fliG and fliY, flagellum-specific ATP synthase gene fliI, flagellar motor switch protein coding gene fliM. These genes might encode some factors and proteins to help the cells to adapt to harsh environment by sensing chemical gradients in their habitats and then move toward more favorable conditions. The interaction between above factors and proteins caused a change in behavior, such as in direction or speed of rotation of flagella (Miller et al., 2009).

Phosphorus (P) acquisition and assimilation are of fundamental importance in cell physiology because $\mathrm{P}$ is a kind of required nutrient in many of the metabolic and energy-producing pathways in bacteria. The phosphorus sources include organic phosphorus and inorganic phosphorus. Bacteria transport inorganic phosphate by high affinity phosphate transport system PstSCAB coded by the pstSCAB operon (Hudek et al., 2016; Martín and Liras, 2021), PhnCDE transport system (coded by the phnCDE gene clusters; Hove-Jensen et al., 2010) and Pit transport systems (coded by pitH gene; Hoffer et al., 2001). Both transport systems are regulated by the two-component system PhoR-PhoP or PhoR-PhoB, and also interact with the phosphate modulator PhoU. To respond to phosphate limitation, some bacteria species may trigger the expression of genes encoding extracellular enzymes, including alkaline phosphatases PhoA (coded by phoA gene), PhoC (coded by phoC gene), and the phospholipase PhoD (coded by phoD gene; Apel et al., 2007; Moura et al., 2001). In the KAAS annotation results of the three strains, phosphate $\mathrm{ABC}$ transporters corresponding genes $p s t S, p s t A, p s t B$, and pst $C$, phosphonate $\mathrm{ABC}$ transporters related genes phnD, phnE and $p h n C$, two component system related genes phoR and phoD were all sorted.
The phenotypic assays showed that all the three strains could assimilate pyrophosphate, thiophosphate, dithiophosphate, phosphoenol pyruvate, 2-deoxy-D-glucose 6-phosphate, and cysteamine-S-phosphate, especially, they could solubilize tricalcium phosphate $\left[\mathrm{Ca}_{3}\left(\mathrm{PO}_{4}\right)_{2}\right]$ and phytin.

Assignment of metabolic pathways via the KEGG database, 2-deoxy-D-glucose-6-phosphate (C06369), dithiophosphate, phosphoenol pyruvate (C00074), and pyrophosphate (C00013) could be predicted from these three strains' metabolic pathway. In the RAST annotation results (Figure 2), the phytase coding gene $(p h y C)$ was retrieved from all the three genomes. It could be proposed that phytase could catalyze the hydrolysis of inorganic orthophosphate from phytin (Kerovuo et al., 1998).

At the genomic level, alkaline phosphatase genes ( $p h o A$, $p h D$ ) and phosphate transport-related genes (phoU, phnC, phnD, phnE, phoB, phoP, phoR, pitH, pstA, pstB, and pstC, and $p s t S)$, as well as inorganic pyrophosphatase coding gene $(p p a)$, phytase coding gene ( $p h y C)$, phosphate starvationinducible protein coding gene $(p h o H)$, and a polyphosphate kinase coding gene ( $p p k)$ were retrieved from all these three genomes (Figure 2). Alkaline phosphatase A was a kind of nonspecific phosphate monoesterase. Alkaline phosphatase D with broad substrate specificity has phosphatase activity toward nucleotide and sugar phosphates (without phosphodiesterase activity; Gomez and Ingram, 1995).

All the genomes of these three strains contained one copy of aglF gene ( $\alpha$-glucoside transport system permease protein AglF coding gene), one copy of aglG gene ( $\alpha$-glucoside transport system permease protein AglG coding gene), one copy of ots $A$ gene (trehalose-phosphate synthase gene), one copy of ots $B$ gene (trehalose 6-phosphate phosphatase gene), two copies of treS genes (maltose alpha-D-glucosyltransferase gene), one copy of treY gene (maltooligosyl trehalose synthase gene), and one copy of treZ gene (malto-oligosyltrehalose trehalohydrolase gene). The proteins coded by these genes reported to be involved in the pathway of trehalose uptake and biosynthesis, which is part of starch and sucrose metabolism (ko00500), and these proteins were supposed to respond to the osmotic stress (Boos et al., 1990; Pan et al., 2008; Reina-Bueno et al., 2012; Chen et al., 2017; MacIntyre et al., 2020). Accumulated trehalose seems to have a major role in protecting the cells from osmotic pressure imbalance. As a major compatible solute, trehalose is involved in the osmotic stress response, cellular adaptation and survival to heat and desiccation stress (Reina-Bueno et al., 2012). The physiological tests results showed that strains CPCC 205119 ${ }^{\mathrm{T}}$, CPCC 205215, and CPCC 205251 could assimilate D-trehalose, which might contributed to maintaining the osmotic balance inside and outside the cell.

In the core genome of the species M. deserti, 96 gene clusters (4.2\%) were mapped to replication and repair (KO09124) contained DNA replication (ko03030), base excision repair (ko03410), nucleotide excision repair (ko03420), mismatch repair (ko03430), homologous recombination (ko03440), and non-homologous end-joining (ko03450) pathway, such as uvrA (UvrABC system protein A coding gene), uvrB (UvrABC system protein $\mathrm{B}$ coding gene), $u v r C$ (UvrABC system protein $\mathrm{C}$ coding gene), $u v r D$ (DNA helicase II coding gene), recA (protein RecA 
coding gene), $r e c B$ (RecBCD enzyme subunit RecB coding gene), $r e c C$ (RecBCD enzyme subunit RecC coding gene), recD (RecBCD enzyme subunit RecD coding gene), recF (DNA replication and repair protein RecF coding gene), recG (ATP-dependent DNA helicase RecG coding gene), recO (DNA repair protein $\mathrm{RecO}$ coding gene), recQ (ATP-dependent DNA helicase RecQ coding gene), and recR (recombination protein RecR coding gene). Thirty-seven gene clusters (1.5\%) were mapped to carbon fixation pathways in prokaryotes (ko00720), such as coxS (carbon monoxide dehydrogenase small chain coding gene), coxM (carbon monoxide dehydrogenase medium chain coding gene), and coxL (carbon monoxide dehydrogenase large chain coding gene). In the core genome, kat $G$ gene (catalase-peroxidase coding gene) was retrieved, and the protein coded by this gene could protect strains against toxic reactive oxygen species (ROS) including hydrogen peroxide as well as organic peroxides. The gene csrA was also retrieved from the core genome, this key regulator could bind to mRNA to regulate the gene expression, thereby, shift from rapid growth to stress survival, or might help the strain to survive in low carbon habitats by activating peptide uptake (Schultz and Matin, 1991; Lucchetti-Miganeh et al., 2008; Rasmussen et al., 2013).

These three strains of the species $M$. deserti showed a wide substrate-assimilation spectrum, including monosaccharide, oligosaccharide, polysaccharide (dextrin), glycerol, hexosephosphates, amino acids, carboxylic acids, fatty acids, and phosphate esters (Supplementary Table S3), which led to the assumption that these strains have evolved to enable access to various carbon sources or to be involved in catabolic pathways. Abundant and various of substrates that could be assimilated contain ester bonds. Own to the abundance of esterases (EC 3.1.1.X) in the strains, they could hydrolyze these ester bonds. So, these esterases might promote these strains survival abilities in dry environments (Bornscheuer, 2002).

Actinobacteria have been well recognized as the prolific producers of natural compounds (Hu et al., 2019; Yang et al., 2021). Typically, Streptomyces spp. and Micromonospora spp. are rich in secondary metabolite synthesis gene clusters (dozens; Carro et al., 2018; Kim et al., 2019). However, the results from antiSMASH database showed that in these three strains of the species $M$. deserti, only seven secondary metabolite gene clusters with moderate similarities to previously described secondary metabolite biosynthetic gene clusters were retrieved (Supplementary Table S5). These gene clusters exhibited $16-100 \%$ similarities to previously reported secondary metabolite biosynthetic gene clusters, such as 5-isoprenylindole-3-carboxylate $\beta$-D-glycosyl easter, alkyl-Odihydrogeranyl-methoxyhydroquinones, arsono-polyketide,

\section{REFERENCES}

Apel, A. K., Sola-Landa, A., Rodríguez-García, A., and Martín, J. F. (2007). Phosphate control of phoA, phoC and phoD gene expression in Streptomyces coelicolor reveals significant differences in binding of $\mathrm{PhoP}$ to their promoter regions. Microbiology 153, 3527-3537. doi: 10.1099/mic.0.2007/007070-0

Auch, A. F., von Jan, M., Klenk, H. P., and Göker, M. (2010). Digital DNADNA hybridization for microbial species delineation by means of genome- desferrioxamine, hiroshidine, isorenieratene and tallysomysin A gene clusters. While abundant stress-responding genes were found in the core genome of the newly established species, which were proposed to contribute greatly to their survival abilities in harsh desert environments. Therefore, the species $M$. deserti might serve as research model organisms for poineer microorganisms adaption and evolution in extreme environments.

\section{DATA AVAILABILITY STATEMENT}

The datasets presented in this study can be found in online repositories. The names of the repository/repositories and accession number(s) can be found in the article/Supplementary Material. The DDBJ/EMBL/GenBank accession numbers for the 16S rRNA gene sequences of strains CPCC $205119^{\mathrm{T}}$, CPCC 205215 and CPCC 205251 are MK392028, MN567210 and MN567664, respectively. This whole genome shotgun projects of strains CPCC $205119^{\mathrm{T}}$, CPCC 205215 and CPCC 205251 have been deposited at DDBJ/ENA/GenBank under the accession numbers JAAGWK000000000, WGGQ00000000 and JAABOZ000000000, respectively.

\section{AUTHOR CONTRIBUTIONS}

Z-MJ, B-HZ, and H-MS carried out the experiments and prepared the manuscript. TZ and L-YY collected the samples. $\mathrm{Y}-\mathrm{QZ}$ designed the research and analyzed the data. All authors contributed to the article and approved the submitted version.

\section{FUNDING}

This research was supported by National Natural Science Foundation of China (32170021 and 31670010), Beijing Natural Science Foundation (5212018), the National Infrastructure of Microbial Resources (NIMR-2021-3), and CAMS Innovation Fund for Medical Sciences (CIFMS; 2016-I2M-2-002).

\section{SUPPLEMENTARY MATERIAL}

The Supplementary Material for this article can be found online at: https://www.frontiersin.org/articles/10.3389/fmicb.2021.742798/ full\#supplementary-material sigs. 531120

Aziz, R. K., Bartels, D., Best, A. A., DeJongh, M., Disz, T., Edwards, R. A., et al. (2008). The RAST server: rapid annotations using subsystems technology. BMC Genomics 9:75. doi: 10.1186/1471-2164-9-75

Blin, K., Shaw, S., Steinke, K., Villebro, R., Ziemert, N., Lee, S. Y., et al. (2019). antiSMASH 5.0: updates to the secondary metabolite genome mining pipeline. Nucleic Acids Res. 47, W81-W87. doi: 10.1093/nar/gkz310 
Boos, W., Ehmann, U., Forkl, H., Klein, W., Rimmele, M., and Postma, P. (1990). Trehalose transport and metabolism in Escherichia coli. J. Bacteriol. 172, 3450-3461. doi: 10.1128/jb.172.6.3450-3461.1990

Bornscheuer, U. T. (2002). Microbial carboxyl esterases: classification, properties and application in biocatalysis. FEMS Microbiol. Rev. 26, 73-81. doi: 10.1111/ j.1574-6976.2002.tb00599.x

Busarakam, K., Bull, A. T., Trujillo, M. E., Riesco, R., Sangal, V., van Wezel, G. P., et al. (2016). Modestobacter caceresii sp. nov., novel actinobacteria with an insight into their adaptive mechanisms for survival in extreme hyper-arid Atacama Desert soils. Syst. Appl. Microbiol. 39, 243-251. doi: 10.1016/j. syapm.2016.03.007

Carro, L., Nouioui, I., Sangal, V., Meier-Kolthoff, J. P., and Trujillo, M. E., Montero-Calasanz, M. D. C., et al. (2018). Genome-based classification of micromonosporae with a focus on their biotechnological and ecological potential. Sci. Rep. 8:525. doi: 10.1038/s41598-017-17392-0

Chaudhari, N. M., Gupta, V. K., and Dutta, C. (2016). BPGA- an ultra-fast pan-genome analysis pipeline. Sci. Rep. 6:24373. doi: 10.1038/srep24373

Chen, X., An, L., Fan, X., Ju, F., Zhang, B., Sun, H., et al. (2017). A trehalose biosynthetic enzyme doubles as an osmotic stress sensor to regulate bacterial morphogenesis. PLoS Genet. 13:e1007062. doi: 10.1371/journal.pgen.1007062

Chouaia, B., Crotti, E., Brusetti, L., Daffonchio, D., Essoussi, I., Nouioui, I., et al. (2012). Genome sequence of Blastococcus saxobsidens DD2, a stoneinhabiting bacterium. J. Bacteriol. 194, 2752-2753. doi: 10.1128/JB. 00320-12

Collins, M. D., Pirouz, T., Goodfellow, M., and Minnikin, D. E. (1977). Distribution of menaquinones in actinomycetes and corynebacteria. J. Gen. Microbiol. 100, 221-230. doi: 10.1099/00221287-100-2-221

Essoussi, I., Ghodhbane-Gtari, F., Amairi, H., Sghaier, H., Jaouani, A., Brusetti, L., et al. (2010). Esterase as an enzymatic signature of Geodermatophilaceae adaptability to Sahara desert stones and monuments. J. Appl. Microbiol. 108, 1723-1732. doi: 10.1111/j.1365-2672.2009.04580.x

Felsenstein, J. (1981). Evolutionary trees from DNA sequences: a maximum likelihood approach. J. Mol. Evol. 17, 368-376. doi: 10.1007/BF01734359

Felsenstein, J. (1985). Confidence limits on phylogenies: an approach using the bootstrap. Evolution 39, 783-791. doi: 10.1111/j.1558-5646.1985. tb00420.x

Golinska, P., Montero-Calasanz, M. D. C., Świecimska, M., Yaramis, A., Igual, J. M., Bull, A. T., et al. (2020). Modestobacter excelsi sp. nov., a novel actinobacterium isolated from a high altitude Atacama Desert soil. Syst. Appl. Microbiol. 43:126051. doi: 10.1016/j.syapm.2019.126051

Golińska, P., Świecimska, M., Montero-Calasanz, M. D. C., Yaramis, A., Igual, J. M., Bull, A. T., et al. (2020). Modestobacter altitudinis sp. nov., a novel actinobacterium isolated from Atacama Desert soil. Int. J. Syst. Evol. Microbiol. 70, 3513-3527. doi: 10.1099/ijsem.0.004212

Gomez, P. F., and Ingram, L. O. (1995). Cloning, sequencing and characterization of the alkaline phosphatase gene ( $p h o D)$ from Zymomonas mobilis. FEMS Microbiol. Lett. 125, 237-245. doi: 10.1111/j.1574-6968.1995.tb07364.x

Groth, I., Schumann, P., Rainey, F. A., Martin, K., Schuetze, B., and Augsten, K. (1997). Demetria terragena gen. nov., sp. nov., a new genus of actinomycetes isolated from compost soil. Int. J. Syst. Bacteriol. 47, 1129-1133. doi: 10.1099/00207713-47-4-1129

Gtari, M., Essoussi, I., Maaoui, R., Sghaier, H., Boujmil, R., Gury, J., et al. (2012). Contrasted resistance of stone-dwelling Geodermatophilaceae species to stresses known to give rise to reactive oxygen species. FEMS Microbiol. Ecol. 80, 566-577. doi: 10.1111/j.1574-6941.2012.01320.x

Hickson, I. D. (2003). RecQ helicases: caretakers of the genome. Nat. Rev. Cancer 3, 169-178. doi: 10.1038/nrc1012

Hoffer, S. M., Uden, N., and Tommassen, J. (2001). Expression of the pho regulon interferes with induction of the $u h p T$ gene in Escherichia coli K-12. Arch. Microbiol. 176, 370-376. doi: 10.1007/s002030100339

Hove-Jensen, B., Rosenkrantz, T. J., Zechel, D. L., and Willemoës, M. (2010). Accumulation of intermediates of the carbon-phosphorus lyase pathway for phosphonate degradation in phn mutants of Escherichia coli. J. Bacteriol. 192, 370-374. doi: 10.1128/JB.01131-09

Hu, X. W., Hu, X. X., Hu, X. M., Li, S. F., Li, L. L., Yu, L. Y., et al. (2019). Cytotoxic and antibacterial cervinomycins B1-4 from a Streptomyces species. J. Nat. Prod. 82, 2337-2342. doi: 10.1021/acs.jnatprod.9b00198

Hudek, L., Premachandra, D., Webster, W. A., and Bräu, L. (2016). Role of phosphate transport system component PstB1 in phosphate internalization by Nostoc punctiforme. Appl. Environ. Microbiol. 82, 6344-6356. doi: 10.1128/ AEM.01336-16

Jaouani, A., Neifar, M., Hamza, A., Chaabouni, S., Martinez, M. J., and Gtari, M. (2012). Purification and characterization of a highly thermostable esterase from the actinobacterium Geodermatophilus obscurus strain G20. J. Basic Microbiol. 52, 653-660. doi: 10.1002/jobm.201100428

Kempf, B., and Bremer, E. (1995). OpuA, an osmotically regulated binding protein-dependent transport system for the osmoprotectant glycine betaine in Bacillus subtilis. J. Biol. Chem. 270, 16701-16713. doi: 10.1074/jbc.270.28.16701

Kerovuo, J., Lauraeus, M., Nurminen, P., Kalkkinen, N., and Apajalahti, J. (1998). Isolation, characterization, molecular gene cloning, and sequencing of a novel phytase from Bacillus subtilis. Appl. Environ. Microbiol. 64, 2079-2085. doi: 10.1128/AEM.64.6.2079-2085.1998

Kim, B., Han, S. R., Lamichhane, J., Park, H., and Oh, T. J. (2019). Draft genome analysis of antimicrobial Streptomyces isolated from himalayan lichen. J. Microbiol. Biotechnol. 29, 1144-1154. doi: 10.4014/jmb.1906.06037

Kim, M., Oh, H. S., Park, S. C., and Chun, J. (2014). Towards a taxonomic coherence between average nucleotide identity and 16S rRNA gene sequence similarity for species demarcation of prokaryotes. Int. J. Syst. Evol. Microbiol. 64, 346-351. doi: 10.1099/ijs.0.059774-0

Kimura, M. (1979). The neutral theory of molecular evolution. Sci. Am. 241, 98-100, 102, 108 passim. doi:10.1038/scientificamerican1179-98

Kluge, A. G., and Farris, J. S. (1969). Quantitative phyletics and the evolution of anurans. Syst. Zool. 18, 1-32. doi: 10.2307/2412407

Kroppenstedt, R. M. (1985). Fatty acid and menaquinone analysis of actinomycetes and related organisms. Soc. Appl. Bacteriol. Tech. Ser. 173-199.

Kumar, S., Stecher, G., Li, M., Knyaz, C., and Tamura, K. (2018). MEGA X: molecular evolutionary genetics analysis across computing platforms. Mol. Biol. Evol. 35, 1547-1549. doi: 10.1093/molbev/msy096

Li, J. S., Bi, Y. T., Dong, C., Yang, J. F., and Liang, W. D. (2011). Transcriptome analysis of adaptive heat shock response of Streptococcus thermophilus. PLoS One 6:e25777. doi: 10.1371/journal.pone.0025777

Li, W. J., Xu, P., Schumann, P., Zhang, Y. Q., Pukall, R., Xu, L. H., et al. (2007). Georgenia ruanii sp. nov., a novel actinobacterium isolated from forest soil in Yunnan (China), and emended description of the genus Georgenia. Int. J. Syst. Evol. Microbiol. 57, 1424-1428. doi: 10.1099/ijs.0.64749-0

Long, L. J., Lee, P. H., Small, E. M., Hillyer, C., Guo, Y., and Osley, M. A. (2020). Regulation of UV damage repair in quiescent yeast cells. DNA Repair 90:102861. doi: 10.1016/j.dnarep.2020.102861

Lorite, M. J., Tachil, J., Sanjuan, J., Meyer, O., and Bedmar, E. J. (2000). Carbon monoxide dehydrogenase activity in Bradyrhizobium japonicum. Appl. Environ. Microbiol. 66, 1871-1876. doi: 10.1128/AEM.66.5.1871-1876.2000

Lowe, T. M., and Eddy, S. R. (1997). tRNAscan-SE: a program for improved detection of transfer RNA genes in genomic sequence. Nucleic Acids Res. 25, 955-964. doi: 10.1093/nar/25.5.955

Lucchetti-Miganeh, C., Burrowes, E., Baysse, C., and Ermel, G. (2008). The post-transcriptional regulator CSRA plays a central role in the adaptation of bacterial pathogens to different stages of infection in animal hosts. Microbiology 154, 16-29. doi: 10.1099/mic.0.2007/012286-0

MacIntyre, A. M., Barth, J. X., Pellitteri-Hahn, M. C., Scarlett, C. O., Genin, S. and Allen, C. (2020). Trehalose synthesis contributes to osmotic stress tolerance and virulence of the bacterial wilt pathogen Ralstonia solanacearum. Mol. Plant-Microbe Interact. 33, 462-473. doi: 10.1094/MPMI-08-19-0218-R

Manthei, K. A., Hill, M. C., Burke, J. E., Butcher, S. E., and Keck, J. L. (2015). Structural mechanisms of DNA binding and unwinding in bacterial RecQ helicases. Proc. Natl. Acad. Sci. U. S. A. 112, 4292-4297. doi: 10.1073/ pnas. 1416746112

Martín, J. F., and Liras, P. (2021). Molecular mechanisms of phosphate sensing, transport and signalling in Streptomyces and related Actinobacteria. Int. J. Mol. Sci. 22:1129. doi: 10.3390/ijms22031129

Martindale, J. L., and Holbrook, N. J. (2002). Cellular response to oxidative stress: signaling for suicide and survival. J. Cell. Physiol. 192, 1-15. doi: $10.1002 /$ jcp. 10119

Meier, A., Kirschner, P., Schröder, K. H., Wolters, J., Kroppenstedt, R. M., and Böttger, E. C. (1993). Mycobacterium intermedium sp. nov. Int. J. Syst. Bacteriol. 43, 204-209. doi: 10.1099/00207713-43-2-204

Meier-Kolthoff, J. P., Auch, A. F., Klenk, H. P., and Göker, M. (2013). Genome sequence-based species delimitation with confidence intervals and improved distance functions. BMC Bioinformatics 14:60. doi: 10.1186/1471-2105-14-60 
Miller, L. D., Russell, M. H., and Alexandre, G. (2009). Diversity in bacterial chemotactic responses and niche adaptation. Adv. Appl. Microbiol. 66, 53-75. doi: 10.1016/s0065-2164(08)00803-4

Ministry of Agriculture of the People's Republic of China (2010). General technical requirements for production strain quality of microbial fertilizer (NY/T 1847-2010). 4-5.

Minnikin, D. E., O’Donnell, A. G., Goodfellow, M., Alderson, G., Athalye, M., Schaal, A., et al. (1984). An integrated procedure for the extraction of bacterial isoprenoid quinones and polar lipids. J. Microbiol. Methods 2, 233-241. doi: 10.1016/0167-7012(84)90018-6

Montero-Calasanz, M. D. C., Yaramis, A., Nouioui, I., Igual, J. M., Spröer, C., Castro, J. F., et al. (2019). Modestobacter italicus sp. nov., isolated from Carrara marble quarry and emended descriptions of the genus Modestobacter and the species Modestobacter marinus, Modestobacter multiseptatus, Modestobacter roseus and Modestobacter versicolor. Int. J. Syst. Evol. Microbiol. 69, 1537-1545. doi: 10.1099/ijsem.0.003282

Moura, R. S., Mart1, J. F., Mart1, N. A., and Liras, P. (2001). Substrate analysis and molecular cloning of the extracellular alkaline phosphatase of Streptomyces griseus. Microbiology 147, 1525-1533. doi: 10.1099/ 00221287-147-6-1525

Normand, P. (2006). Geodermatophilaceae fam. nov., a formal description. Int. J. Syst. Evol. Microbiol. 56, 2277-2278. doi: 10.1099/ijs.0.64298-0

Normand, P., Gury, J., Pujic, P., Chouaia, B., Crotti, E., Brusetti, L., et al. (2012). Genome sequence of radiation-resistant Modestobacter marinus strain BC501, a representative actinobacterium that thrives on calcareous stone surfaces. J. Bacteriol. 194, 4773-4774. doi: 10.1128/JB.01029-12

Page, A. J., Cummins, C. A., Hunt, M., Wong, V. K., Reuter, S., Holden, M., et al. (2015). Roary: rapid large-scale prokaryote pan genome analysis. Bioinformatics 31, 3691-3693. doi: 10.1093/bioinformatics/btv421

Pan, Y. T., Carroll, J. D., Asano, N., Pastuszak, I., Edavana, V. K., and Elbein, A. D. (2008). Trehalose synthase converts glycogen to trehalose. FEBS J. 275, 3408-3420. doi: 10.1111/j.1742-4658.2008.06491.x

Pasamontes, L., Haiker, M., Wyss, M., Tessier, M., and Loon-van, A. P. (1997). Gene cloning, purification, and characterization of a heat-stable phytase from the fungus Aspergillus fumigatus. Appl. Environ. Microbiol. 63, 1696-1700. doi: 10.1128/aem.63.5.1696-1700.1997

Qin, Q. L., Xie, B. B., Zhang, X. Y., Chen, X. L., Zhou, B. C., Zhou, J., et al. (2014). A proposed genus boundary for the prokaryotes based on genomic insights. J. Bacteriol. 196, 2210-2215. doi: 10.1128/JB.01688-14

Rasmussen, J. J., Vegge, C. S., Frokiaer, H., Howlett, R. M., Krogfelt, K. A., Kelly, D. J., et al. (2013). Campylobacter jejuni carbon starvation protein a (CSTA) is involved in peptide utilization, motility and agglutination, and has a role in stimulation of dendritic cells. J. Med. Microbiol. 62, 1135-1143. doi: $10.1099 / \mathrm{jmm} .0 .059345-0$

Reina-Bueno, M., Argandona, M., Nieto, J. J., Hidalgo-Garcia, A., Iglesias-Guerra, F., Delgado, M. J., et al. (2012). Role of trehalose in heat and desiccation tolerance in the soil bacterium Rhizobium etli. BMC Microbiol. 12:207. doi: 10.1186/1471-2180-12-207

Rodriguez-R, L. M., and Konstantinidis, K. (2014). Bypassing cultivation to identify bacterial species. Microbe Magazine 9, 111-118. doi: 10.1128/ microbe.9.111.1

Rodriguez-R, L. M., and Konstantinidis, K. T. (2016). The enveomics collection: a toolbox for specialized analyses of microbial genomes and metagenomes. PeerJ Preprints 4:e1900v1. doi: 10.7287/peerj.preprints.1900v1

Romeo, T. (1998). Global regulation by the small RNA-binding protein CsrA and the non-coding RNA molecule CsrB. Mol. Microbiol. 29, 1321-1330. doi: $10.1046 /$ j.1365-2958.1998.01021.x

Romeo, T., Gong, M., Liu, M. Y., and Brun-Zinkernagel, A. M. (1993). Identification and molecular characterization of csrA, a pleiotropic gene from Escherichia coli that affects glycogen biosynthesis, gluconeogenesis, cell size, and surface properties. J. Bacteriol. 175, 4744-4755. doi: 10.1128/jb.175.15.4744-4755.1993

Schleifer, K. H., and Kandler, O. (1972). Peptidoglycan types of bacterial cell walls and their taxonomic implications. Bacteriol. Rev. 36, 407-477. doi: 10.1128/br.36.4.407-477.1972

Schultz, J. E., and Matin, A. (1991). Molecular and functional characterization of a carbon starvation gene of Escherichia coli. J. Mol. Biol. 218, 129-140. doi: 10.1016/0022-2836(91)90879-B

Sghaier, H., Hezbri, K., Ghodhbane-Gtari, F., Pujic, P., Sen, A., Daffonchio, D., et al. (2016). Stone-dwelling actinobacteria Blastococcus saxobsidens,
Modestobacter marinus and Geodermatophilus obscurus proteogenomes. ISME J. 10, 21-29. doi: 10.1038/ismej.2015.108

Shand, R. F., and Betlach, M. C. (1994). bop gene cluster expression in bacteriorhodopsin-overproducing mutants of Halobacterium halobium. J. Bacteriol. 176, 1655-1660. doi: 10.1128/jb.176.6.1655-1660.1994

Shirlng, E. B., and Gottlieb, D. (1966). Methods for characterization of Streptomyces species. Int. J. Syst. Bacteriol. 16, 313-340. doi: 10.1099/00207713-16-3-313

Song, Y., Jiang, C. Y., Liang, Z. L., Wang, B. J., Jiang, Y., Yin, Y., et al. (2020). Casimicrobium huifangae gen. nov., sp. nov., a Ubiquitous "Most-Wanted" core bacterial taxon from municipal wastewater treatment plants. Appl. Environ. Microbiol. 86:e02209-19. doi: 10.1128/AEM.02209-19

Staneck, J. L., and Roberts, G. D. (1974). Simplified approach to identification of aerobic actinomycetes by thin-layer chromatography. Appl. Microbiol. 28, 226-231. doi: 10.1128/am.28.2.226-231.1974

Sun, H. M., Zhang, T., Yu, L. Y., Sen, K., and Zhang, Y. Q. (2015). Ubiquity, diversity and physiological characteristics of Geodermatophilaceae in Shapotou National Desert Ecological Reserve. Front. Microbiol. 6:1059. doi: 10.3389/ fmicb.2015.01059

Tanaka, T., Kawasaki, K., Daimon, S., Kitagawa, W., Yamamoto, K., Tamaki, H., et al. (2014). A hidden pitfall in the preparation of agar media undermines microorganism cultivability. Appl. Environ. Microbiol. 80, 7659-7666. doi: 10.1128/AEM.02741-14

Trujillo, M. E., Goodfellow, M., Busarakam, K., and Riesco, R. (2015). Modestobacter lapidis sp. nov. and Modestobacter muralis sp. nov., isolated from a deteriorated sandstone historic building in Salamanca, Spain. Antonie Van Leeuwenhoek 108, 311-320. doi: 10.1007/s10482-015-0482-7

Xu, P., Li, W. J., Tang, S. K., Zhang, Y. Q., Chen, G. Z., Chen, H. H., et al. (2005). Naxibacter alkalitolerans gen. nov., sp. nov., a novel member of the family 'Oxalobacteraceae' isolated from China. Int. J. Syst. Evol. Microbiol. 55, 1149-1153. doi: 10.1099/ijs.0.63407-0

Yang, X., Zhu, Z. H., Ji, X., Liu, Z. M., Zhang, H., and Wei, B. (2021). Complete genome sequence of Micromonospora craniellae LHW63014T, a potential metal ion-chelating agent producer. Mar. Genomics 57:100830. doi: 10.1016/j. margen.2020.100830

Yoon, S. H., Ha, S. M., Kwon, S., Lim, J., Kim, Y., Seo, H., et al. (2017a). Introducing EzBioCloud: a taxonomically united database of $16 \mathrm{~S}$ rRNA gene sequences and whole-genome assemblies. Int. J. Syst. Evol. Microbiol. 67, 1613-1617. doi: 10.1099/ijsem.0.001755

Yoon, S.-H., Ha, S.-M., Lim, J., Kwon, S., and Chun, J. (2017b). A large-scale evaluation of algorithms to calculate average nucleotide identity. Antonie Van Leeuwenhoek 110, 1281-1286. doi: 10.1007/s10482-017-0844-4

Yuan, L. J., Zhang, Y. Q., Guan, Y., Wei, Y. Z., Li, Q. P., Yu, L. Y., et al. (2008). Saccharopolyspora antimicrobica sp. nov., an actinomycete from soil. Int. J. Syst. Evol. Microbiol. 58, 1180-1185. doi: 10.1099/ijs.0.65532-0

Zhang, B. H., Salam, N., Cheng, J., Li, H. Q., Yang, J. Y., Zha, D. M., et al. (2016). Modestobacter lacusdianchii sp. nov., a phosphate-solubilizing actinobacterium with ability to promote microcystis growth. PLoS One 11:e0161069. doi: 10.1371/journal.pone.0161069

Zhou, Z. H., Liu, Z. H., Qian, Y. D., Kim, S. B., and Goodfellow, M. (1998). Saccharopolyspora spinosporotrichia sp. nov., a novel actinomycete from soil. Int. J. Syst. Bacteriol. 48(Pt 1), 53-58. doi: 10.1099/00207713-48-1-53

Conflict of Interest: The authors declare that the research was conducted in the absence of any commercial or financial relationships that could be construed as a potential conflict of interest.

Publisher's Note: All claims expressed in this article are solely those of the authors and do not necessarily represent those of their affiliated organizations, or those of the publisher, the editors and the reviewers. Any product that may be evaluated in this article, or claim that may be made by its manufacturer, is not guaranteed or endorsed by the publisher.

Copyright () 2021 Jiang, Zhang, Sun, Zhang, Yu and Zhang. This is an open-access article distributed under the terms of the Creative Commons Attribution License (CC BY). The use, distribution or reproduction in other forums is permitted, provided the original author(s) and the copyright owner(s) are credited and that the original publication in this journal is cited, in accordance with accepted academic practice. No use, distribution or reproduction is permitted which does not comply with these terms. 